\title{
Brucellosis and tuberculosis in cattle in South America
}

\section{Brucelose e tuberculose bovinas na América do Sul}

\author{
José Soares FERREIRA NETO ${ }^{1}$
}

\author{
${ }^{1}$ Universidade de São Paulo, Faculdade de Medicina Veterinária e Zootecnia, \\ Departamento de Medicina Veterinária Preventiva e Saúde Animal, São Paulo - SP, Brazil
}

\begin{abstract}
In general, European and North American countries, as well as Australia and New Zealand, have already eradicated or reached good levels of control of brucellosis and tuberculosis in cattle. In the rest of the world, however, the epidemiological situation of these two diseases is frequently poorly understood. In this review article, quantified data on these diseases in the South American countries are presented. Initially, the aspects that led the continent to host $25 \%$ of the world cattle population are presented, in addition to the aspects that placed the continent at a prominent position in the international meat market. Subsequently the continent was divided into three country groups, considering the size of the cattle population and how well the epidemiological situation of brucellosis and tuberculosis in cattle is quantified. It is argued that countries that do not generate high-quality quantitative epidemiological data on these diseases have serious limitations in outlining and managing control or eradication strategies. Thus, for successful outcomes, at least methodologies to estimate the prevalence of infected herds should be employed.
\end{abstract}

Keywords: Bovine brucellosis. Bovine tuberculosis. South America. Epidemiological situation.

\section{Resumo}

De maneira geral, os países da Europa e da América do Norte, além da Austrália e da Nova Zelândia, já erradicaram ou atingiram bons níveis de controle da brucelose e da tuberculose bovinas. Entretanto, no restante do mundo, raramente a situação epidemiológica dessas duas doenças é adequadamente conhecida. Neste artigo de revisão são apresentados dados de quantificação dessas importantes enfermidades nos países da América do Sul. Inicialmente são apresentadas as características que concorreram para que atualmente o continente tenha $25 \%$ do efetivo bovino mundial e uma posição de destaque no mercado internacional de carnes. Os países foram então alocados em três grupos, levando em consideração o tamanho da população bovina e a qualidade da quantificação referente à situação epidemiológica da brucelose e da tuberculose bovinas. Argumenta-se que países que não geram dados epidemiológicos quantitativos de alta qualidade em relação a essas doenças têm sérias limitações para traçar estratégias eficazes de combate e são incapazes de realizar a gestão dos processos. Conclui-se que os países que desejam ser exitosos no combate à brucelose e tuberculose bovinas deveriam ao menos utilizar metodologias para estimar a prevalência de focos.

Palavras-chave: Brucelose bovina. Tuberculose bovina. América do Sul. Situação epidemiológica.

\section{Correspondence to:}

José Soares Ferreira Neto

Universidade de São Paulo, Faculdade de Medicina Veterinária e Zootecnia

Av. Prof. Dr. Orlando Marques de Paiva, 87 - Cidade Universitária

CEP 05508-270, São Paulo, SP, Brazil

e-mail: jsoares@vps.fmvz.usp.br

Received: $29 / 11 / 2017$

Approved: 28/2/2018

\section{Characterization of South America}

South America holds 12\% of the land area and 6\% of the world's human population. The continent is composed of twelve sovereign countries and a French overseas region, as well as island territories in the southern Caribbean and
Atlantic. In the Venezuelan Caribbean is the sovereign state of Trinidad Tobago and the islands Aruba, Bonaire and Curaçao, Dutch possessions; in the South Atlantic, the Falklands, South Georgia and the South Sandwich Islands, all British possessions.

The majority of South American countries speak Spanish. Portuguese is spoken only in Brazil and French only in French Guiana. English is spoken in Guiana, Trinidad Tobago, and the insular British possessions. Dutch is spoken in Suriname and in insular Dutch possessions.

Geographically, the continent has a long mountain chain (the Andes) and a desert region (the Atacama Desert) to the west, a dense rainforest in the north, a marshland 
in its middle portion that represents a continental drain (Pantanal/Chaco), and plains and plateau regions of equatorial, tropical, subtropical, and temperate climates, very conducive to agriculture and livestock. South
America holds approximately a quarter of the world's cattle population. Furthermore, $75 \%$ of these animals are found in only two countries, Brazil and Argentina (Table 1, Figure 1).

Table 1 - Geographic area and data on human and cattle population in South American countries

\begin{tabular}{|c|c|c|c|c|c|c|}
\hline \multicolumn{2}{|r|}{ Country } & \multirow{2}{*}{ 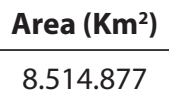 } & \multirow{2}{*}{$\begin{array}{c}\text { Human population* } \\
202.241 .714\end{array}$} & \multirow{2}{*}{$\begin{array}{c}\text { Cattle population" } \\
211.764 .292\end{array}$} & \multirow{2}{*}{$\frac{\%}{60,78}$} & \multirow{2}{*}{$\begin{array}{c}\text { cattle / human } \\
1,05\end{array}$} \\
\hline 1 & Brazil & & & & & \\
\hline 2 & Argentina & 2.766 .890 & 40.482 .000 & 51.095 .000 & 14,66 & 1,26 \\
\hline 3 & Colombia & 1.141 .748 & 46.920 .000 & 23.141 .388 & 6,64 & 0,49 \\
\hline 4 & Venezuela & 916.445 & 31.648 .930 & 14.500 .000 & 4,16 & 0,46 \\
\hline 5 & Paraguay & 406.750 & 6.831 .306 & 13.376 .456 & 3,84 & 1,96 \\
\hline 6 & Uruguay & 176.220 & 3.477 .780 & 11.500 .000 & 3,30 & 3,31 \\
\hline 7 & Bolivia & 1.098 .580 & 9.863 .000 & 8.847 .434 & 2,54 & 0,90 \\
\hline 8 & Peru & 1.285 .220 & 29.132 .013 & 5.556 .188 & 1,59 & 0,19 \\
\hline 9 & Ecuador & 283.560 & 14.573 .101 & 5.134 .122 & 1,47 & 0,35 \\
\hline 10 & Chile & 756.950 & 16.928 .873 & 3.305 .365 & 0,95 & 0,20 \\
\hline 11 & Guyana & 214.999 & 772.298 & 112.900 & 0,03 & 0,15 \\
\hline 12 & Suriname & 163.270 & 472.000 & 46.060 & 0,01 & 0,10 \\
\hline 13 & Trinidad and Tobago & 5.131 & 1.349 .667 & 34.500 & 0,01 & 0,03 \\
\hline 14 & French Guiana (France) & 91.000 & 221.500 & 18.370 & 0,01 & 0,08 \\
\hline 15 & Falkland Islands (UK) & 12.173 & 3.140 & 4.300 & 0,00 & 1,37 \\
\hline 16 & Aruba, Bonaire, Curaçao (Netherlands) & 931 & 260.675 & & 0,00 & \\
\hline 17 & South Georgia, South Sandwich Islands (UK) & 3.093 & 30 & & 0,00 & \\
\hline TOT & & 17.837 .837 & 405.178 .027 & 348.436 .375 & 100,0 & \\
\hline
\end{tabular}

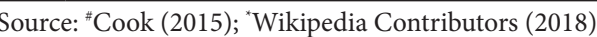

a)

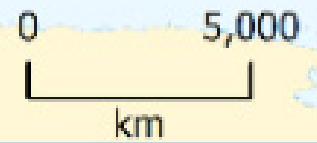

\section{Head per $\mathrm{km}^{2}$}

$<1$

$1-5$
$5-10$

$10-20$
$20-50$

$50-100$

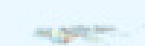

רert

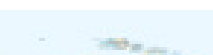

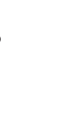


This enormous cattle population, combined with the existence of vast areas free from foot-and-mouth disease (FMD) and a negligible risk for bovine spongiform encephalopathy (BSE) (Figures 2 and 3), contributed to the economy of several South American countries, particularly Brazil, Uruguay, Paraguay, and Argentina, which stood out as meat exporters in the world market.

\section{Conducting review and organizing information}

The information contained in this article were extracted exclusively from a survey spanning the last sixteen years in the following data sources: PubMed, ScienceDirect, Scopus, SciELO, Wiley Online Library, Google Scholar, Google Search.

It must be pointed out that the official veterinary services of these countries were not contacted to obtain information on the epidemiological situation or strategies of combating brucellosis and tuberculosis in cattle.

After an extensive search in the bibliographical material, the information on the epidemiological situation of these diseases was separated into three blocks of countries:

1) Countries with very small cattle populations: Guiana, Suriname, French Guiana, Trinidad and Tobago, Aruba, Bonaire, Curacao, Falkland Islands, South Georgia, and South Sandwich Islands;

2) Countries where the epidemiological situation of brucellosis and tuberculosis in cattle is not properly characterized: Venezuela, Colombia, Ecuador, Peru, Bolivia, and Paraguay;

3) Countries where the epidemiological situation of brucellosis and tuberculosis in cattle is properly characterized: Chile, Uruguay, Argentina, and Brazil.

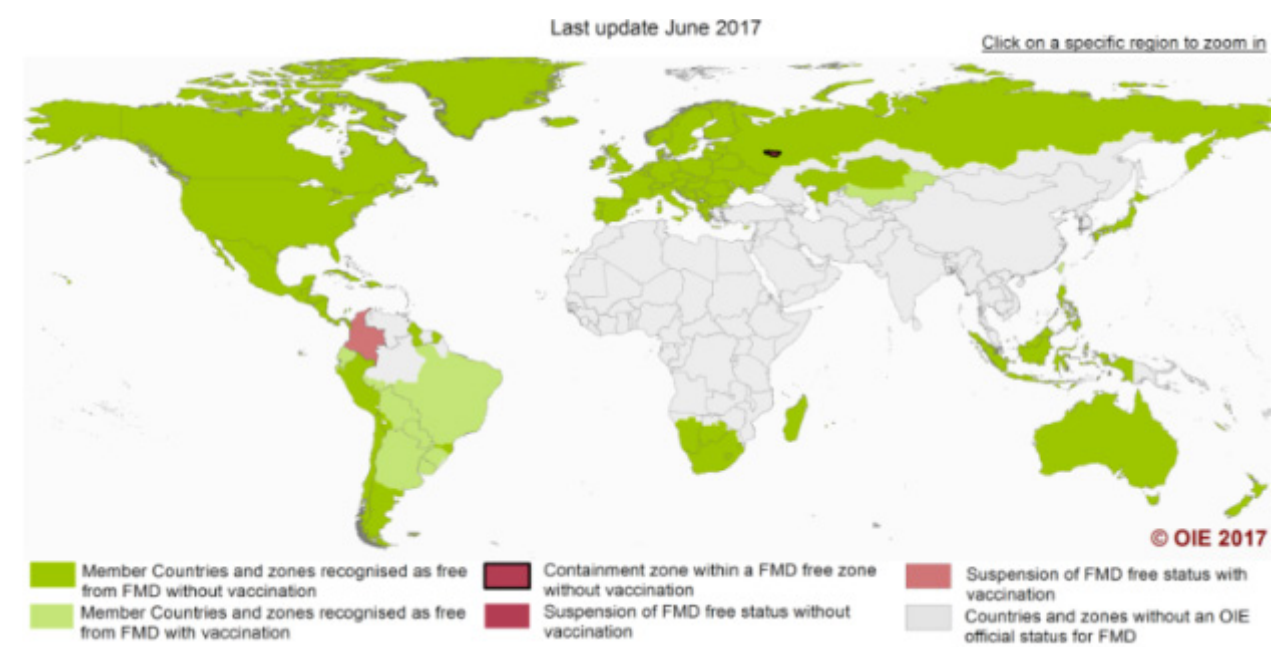

Figure 2 - Official foot-and-mouth disease (FMD) risk status map of the World Organisation for Animal Health (OIE) member countries

Source: World Organisation for Animal Health (2017)

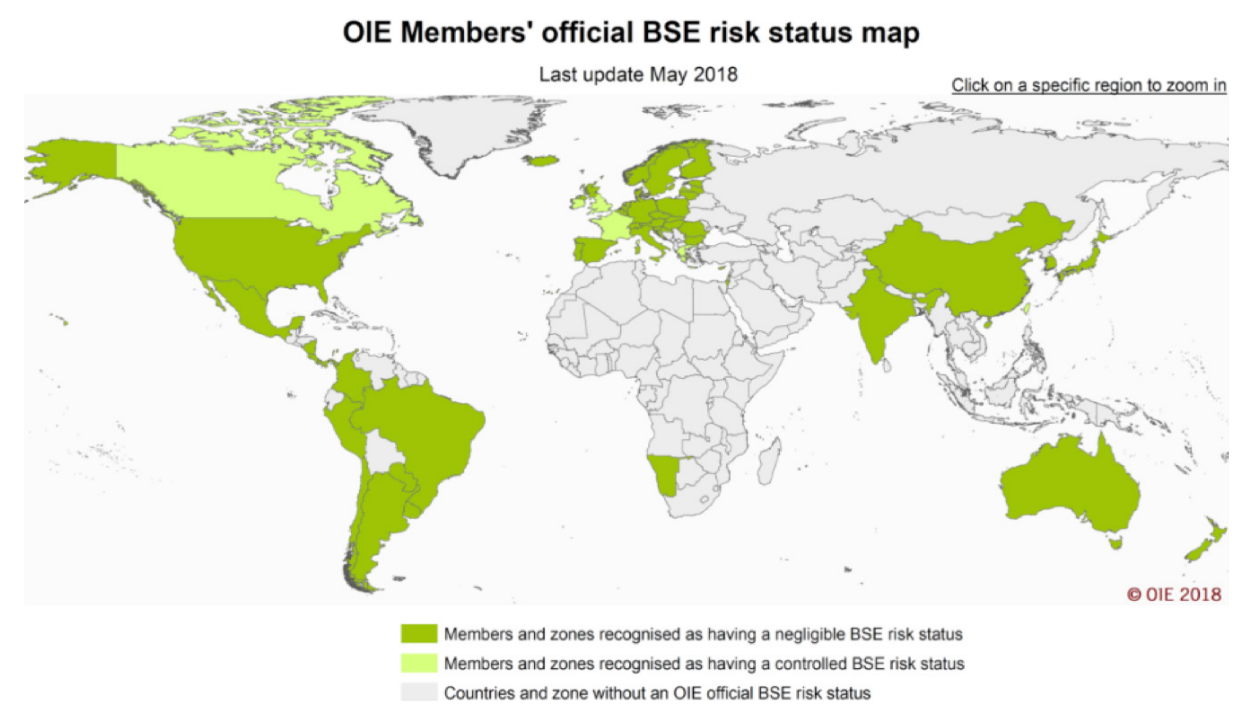

Figure 3 - Official bovine spongiform encephalopathy (BSE) risk status map of the World Organisation for Animal Health (OIE) member countries

Source: World Organisation for Animal Health (2018) 


\section{Situation of brucellosis and tuberculosis in cattle in countries with very small cattle populations}

The cattle populations of Guiana, Suriname, French Guiana, Trinidad and Tobago, Aruba, Bonaire, Curacao, Falkland Islands, South Georgia and South Sandwich Islands amount to a little more than 216,000 heads, which represent $0.06 \%$ of the cattle population in South America (Table 2). The
OIE online database, Handistatus II, provides data on the last occurrence, as well as the strategies adopted for brucellosis and tuberculosis, but only to Suriname, Trinidad and Tobago, French Guiana, and Falklands Islands (Table 2). There seems to be no cattle population in Aruba, Bonaire, Curacao, South Georgia, and South Sandwich Islands. No data were found on the occurrence of disease in Guiana (Table 2).

Table 2 - Data on bovine brucellosis and tuberculosis in South American countries with very small cattle populations

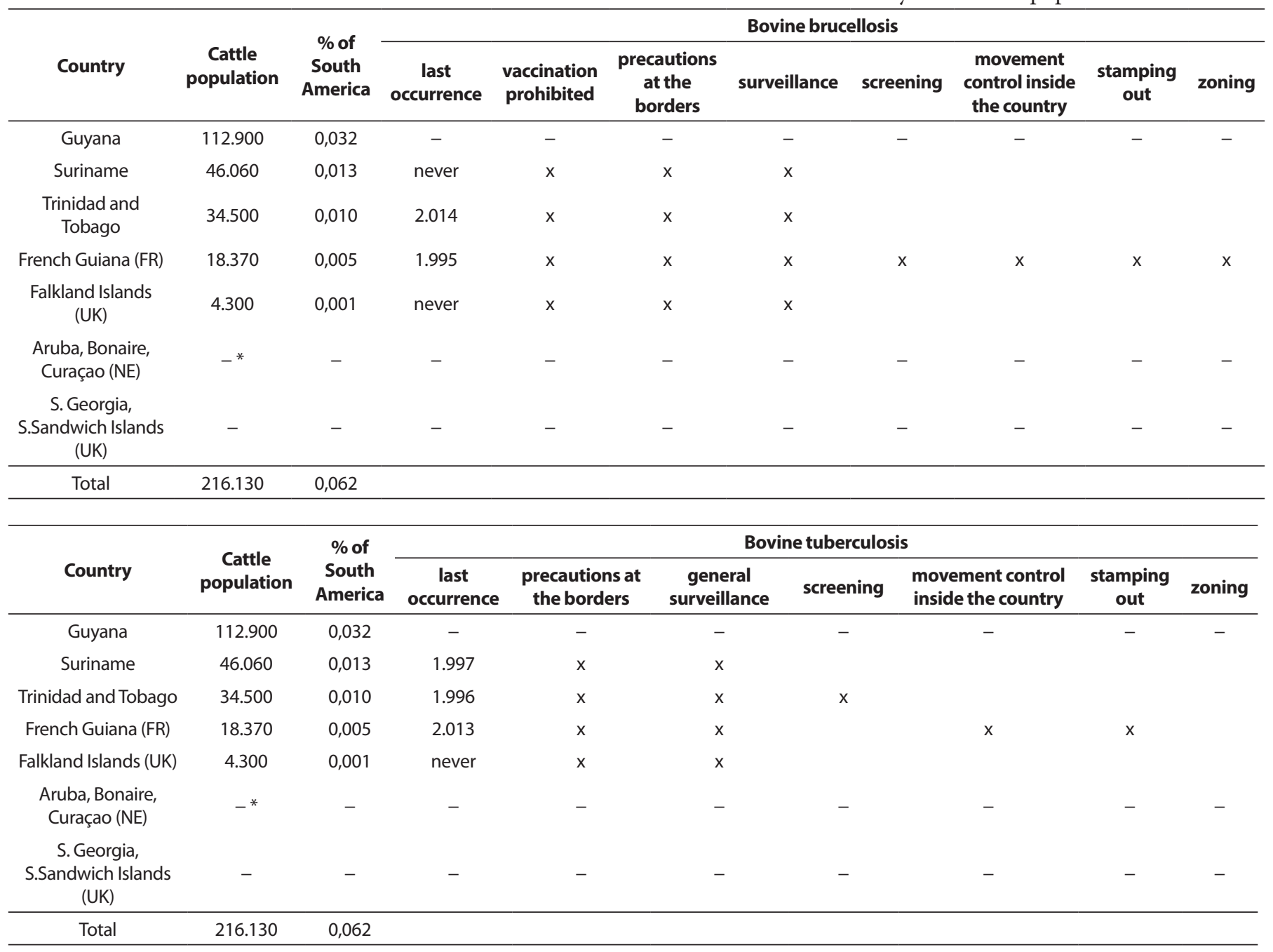

* information not available

Source: World Organisation for Animal Health (2014)

In conclusion, in addition to their extremely small cattle populations, the occurrence of brucellosis and tuberculosis in cattle in these countries and territories seems to be sporadic.

\section{Countries where the epidemiological situation of brucellosis and tuberculosis in cattle is not properly characterized}

This group is composed of six countries, namely Venezuela, Colombia, Ecuador, Peru, Bolivia, and Paraguay, which account for $20 \%$ of the cattle population in South America (Table 1).

The information available shows that there are no nationwide data about the situation of the diseases in all states and regions. With rare exceptions, small-sized studies, with little or no details on sample design and covering a small geographic region, are occasionally found. The results, for both diseases, almost always indicate significant differences in their prevalence between regions and/or between periods of time. The detailed situation of each country is described below. 


\section{Venezuela}

Studies on cattle brucellosis in Venezuela are summarized in table 3 . The results show striking regional differences in the prevalence of animals and the prevalence data of infected herds only for locations in the state of Lara.
Table 4 provides a historical series of official data on the epidemiological situation of bovine tuberculosis, with significant numbers of properties and animals tested annually. However, the nearly 12 -fold increase in the prevalence of animals from 1995 to 2001 confirms the inaccuracy of these data, considering that tuberculosis is a chronic disease of slow spread.

Table 3 - Studies on the epidemiological situation of bovine brucellosis in Venezuela

\begin{tabular}{|c|c|c|c|c|c|c|c|}
\hline \multirow{2}{*}{ Author } & \multirow{2}{*}{ Year } & \multirow{2}{*}{ Location } & \multirow{2}{*}{ Test } & \multicolumn{2}{|c|}{ Herds } & \multicolumn{2}{|c|}{ Animals } \\
\hline & & & & Tested & $\%$ Positive & Tested & $\%$ Positive \\
\hline $\begin{array}{l}\text { Vargas, 2002, reporting } \\
\text { different authors }\end{array}$ & $\begin{array}{l}\text { prior to } \\
2002\end{array}$ & many regions & $\begin{array}{c}\text { ELISA, CFT, } \\
\text { agglutination Tests }\end{array}$ & & & & 0,8 to 10,5 \\
\hline D'Pool et al., 2004 & 1999 & $\begin{array}{l}\text { La Cañada de Urdaneta } \\
\text { municipality }\end{array}$ & C-ELISA + 2ME & & & 384 & 9,1 \\
\hline Mosquera et al., 2009 & $2006 / 07$ & $\begin{array}{c}\text { Buria County, Simón Planas } \\
\text { municipality, Lara state }\end{array}$ & Ring Test (milk) & 134 & 15,20 & & \\
\hline Maldonado et al., 2010 & 2007 & Lara state & ELISA (milk) & 258 & 13,14 & & \\
\hline
\end{tabular}

Table 4 - Historical series of official data on the situation of bovine tuberculosis in Venezuela

\begin{tabular}{|c|c|c|c|c|c|c|}
\hline \multirow{2}{*}{ Year } & \multicolumn{3}{|c|}{ Herds } & \multicolumn{3}{|c|}{ Animals } \\
\hline & Tested & Positive & $\%$ Positive & Tested & Positive & $\%$ Positive \\
\hline 1995 & 3.716 & 93 & 2,50 & 1.060 .967 & 218 & 0,021 \\
\hline 1996 & 3.962 & 84 & 2,12 & 1.140 .565 & 343 & 0,030 \\
\hline 1997 & 2.861 & 74 & 2,59 & 729.560 & 326 & 0,045 \\
\hline 2000 & 3.892 & 131 & 3,37 & 920.625 & 556 & 0,060 \\
\hline 2001 & 1.982 & 119 & 6,00 & 340.883 & 845 & 0,248 \\
\hline 2002 & 1.301 & 105 & 8,07 & 480.002 & 732 & 0,152 \\
\hline 2003 & 2.708 & 133 & 4,91 & 779.847 & 325 & 0,042 \\
\hline 2004 & 1.958 & 69 & 3,52 & 447.260 & 314 & 0,070 \\
\hline 2005 & 1.250 & 45 & 3,60 & 276.988 & 435 & 0,157 \\
\hline 2006 & 1.483 & 67 & 4,52 & 342.215 & 362 & 0,106 \\
\hline
\end{tabular}

Source: data have been reported by Rivera and Giménez (2010)

\section{Colombia}

Official data from the Colombian Agricultural Institute (ICA) indicated a $22 \%$ prevalence of infected herds and 5\% prevalence of animals in 2006 (Table 5). Even though neither recent data nor accurate information on the situation of brucellosis in the whole Colombian territory have been found, the ICA website reports information on a free herd and free zone accreditation program (Figure 4, Table 6). Figure 4 shows two areas declared free of cattle brucellosis (in yellow): one area is located in the north of the country, including regions of the states of Santander and Boyacá, and another area is represented by the archipelago of San Andre and Providence. Table 6 summarizes the number of properties accredited as free in Colombian states, highlighting Plan Narinõ, Cundinamarca, and Antioquia, which accreditated $55 \%, 17 \%$, and $11 \%$ of their herds, respectively.

Regarding bovine tuberculosis, although the ICA site states that the prevalence is less than $1 \%, 3.1 \%$ of the 7,951 animals tested by tuberculin between 2005 and 2009 were positive, mainly in the states of San Andrés, César, Cundinamarca and Antioquia (WARD, 2010). Notwithstanding the inconsistent data on the disease situation in Colombia, the country has been promoting a free herd accreditation program, the results of which are listed in table 6. 


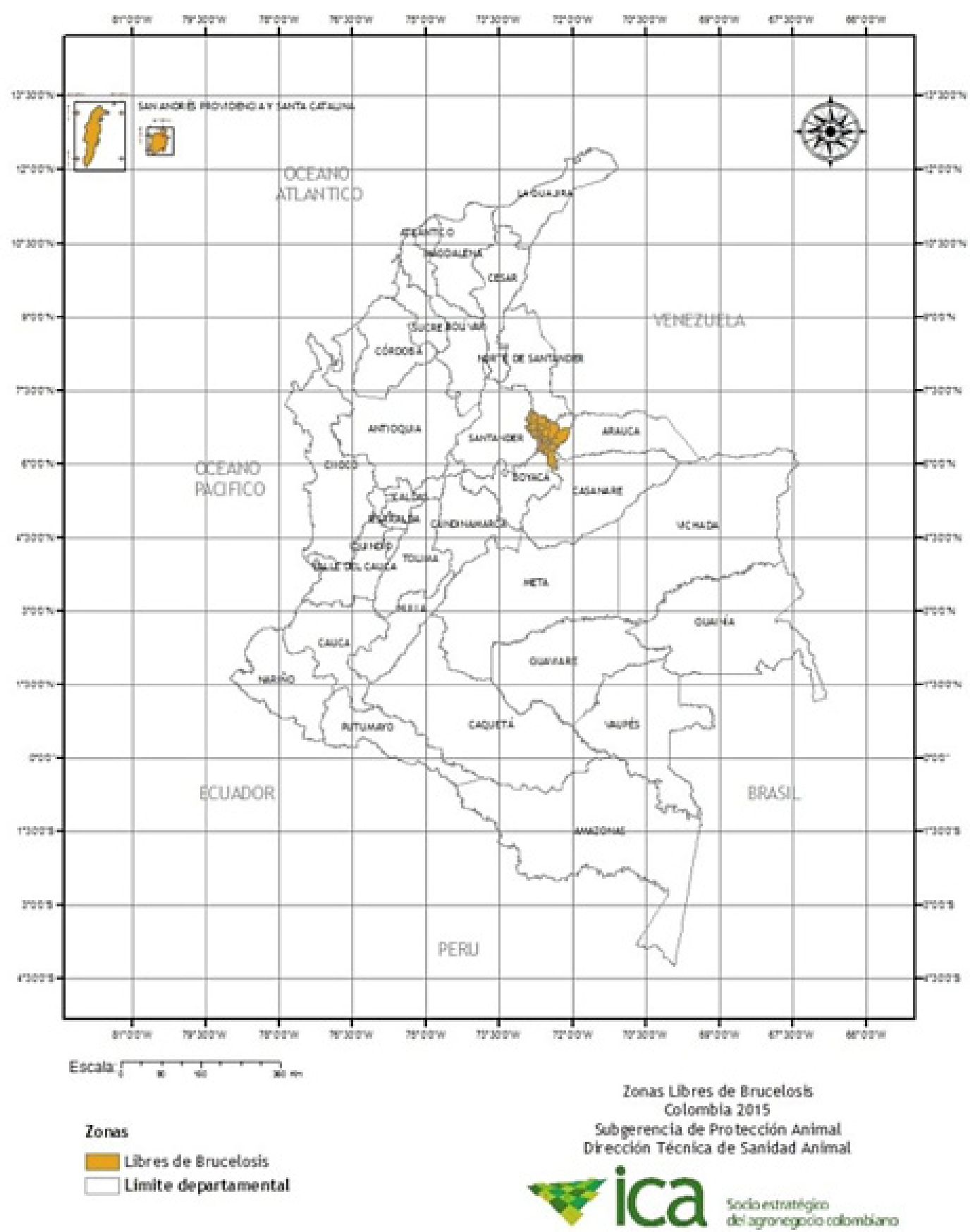

Figure 4 - Bovine brucellosis-free zones declared by the Colombian Agricultural Institute Source: Colombia (2016)

Table 5 - Reports on the epidemiological situation of bovine brucellosis in Colombia

\begin{tabular}{|c|c|c|c|c|c|c|c|}
\hline Author & Year & Location & Test & Tested Herds & \% Positive & Tested Animals & $\%$ Positive \\
\hline Aricapa et al., 2008 & 2001-2002 & Caldas & $\mathrm{RBT}+\mathrm{CFT}$ & & & 2.434 & 0,6 \\
\hline $\begin{array}{l}\text { ICA apud Tique et al., } \\
2009\end{array}$ & 2006 & national & $?$ & 3.976 & 22,0 & 226.941 & 5,0 \\
\hline Tique et al., 2009 & $2006-2008$ & Córdoba & RBT / ELISA & 4.922 & 12,7 & 29.969 & 3,71 \\
\hline Giraldo et al., 2014 & $?$ & $\begin{array}{l}\text { Caquetá and } \\
\text { Putumayo }\end{array}$ & RBT + C-ELISA & 7 & & & $\begin{array}{c}\text { 11,9 (buffaloes) } \\
\text { 5,3 (bovines) }\end{array}$ \\
\hline Giraldo et al., 2014 & $?$ & $\begin{array}{l}\text { Caquetá and } \\
\text { Putumayo }\end{array}$ & RBT + C-ELISA & 7 & & & $\begin{array}{c}11.9 \text { (buffaloes) } \\
5.3 \text { (bovines) }\end{array}$ \\
\hline
\end{tabular}


Table 6 - Number of official brucellosis-free herds (up to December 2016) and official tuberculosis-free herds (up to 2010) in the Colombian states

\begin{tabular}{|c|c|c|c|c|c|}
\hline State & Brucellosis * & Tuberculosis ** & State & Brucellosis * & Tuberculosis ** \\
\hline Amazonas & - & 7 & Huila & 106 & 27 \\
\hline Antioquia & 3.297 & 1.022 & La Guajira & 9 & - \\
\hline Arauca & 35 & - & Magdalena & 8 & - \\
\hline Atlántico & 17 & 10 & Meta & 15 & 19 \\
\hline Bolivar & 17 & - & Nariño & 10.452 & 99 \\
\hline Boyacá & 658 & 51 & Norte de Santander & 143 & 5 \\
\hline Caldas & 213 & 58 & Putumayo & 375 & 38 \\
\hline Caquetá & 384 & 47 & Quindío & 39 & 765 \\
\hline Casanare & 194 & 41 & Risaralda & 154 & 80 \\
\hline Cauca & 169 & 15 & San Andres & - & - \\
\hline Cesar & 43 & 9 & Santander & 119 & 158 \\
\hline Chocó & - & - & Sucre & 29 & 4 \\
\hline Córdoba & 86 & 18 & Tolima & 98 & 365 \\
\hline Cundinamarca & 2.181 & 838 & Valle del Cauca & 98 & 29 \\
\hline Guainía & 1 & - & Vaupués & 4 & - \\
\hline Guaviare & 52 & - & Vichada & - & - \\
\hline subtotal & 7.347 & 2.116 & subtotal & 11.649 & 1.589 \\
\hline Grand Total & & & & 18.996 & 3.705 \\
\hline
\end{tabular}

Source: Colombia $\left(2010^{* *} ; 2016^{*}\right)$

\section{Ecuador}

Recent studies on the prevalence of brucellosis-infected herds in Ecuador indicated major regional differences, suggesting that the disease occurs throughout the country, but in a rather heterogeneous way (Table 7).

Pérez et al. (2011) reviewed the situation of cattle tuberculosis in Ecuador, and the data are summarized in figures 5 and 6 . The data from several authors listed in the tables revealed that the disease is more prevalent in properties where milk is produced, especially in the provinces of Pichincha and Imbabura. However, although the studies did not provide a comprehensive view of all the national territory, they suggested the existence of large regional differences.

Table 7 - Studies of the epidemiological situation of bovine brucellosis in Ecuador

\begin{tabular}{|c|c|c|c|c|c|c|c|}
\hline \multirow{2}{*}{ Author } & \multirow{2}{*}{ Year } & \multirow{2}{*}{ Location } & \multirow{2}{*}{ Test } & \multicolumn{2}{|c|}{ Heds } & \multicolumn{2}{|r|}{ Animals } \\
\hline & & & & Tested & $\%$ Positive & Tested & \% Positive \\
\hline Aguayo et al., 2015 & $2014-2015$ & Manabí & RBT + C-ELISA & 163 & $10,43 \%$ & 2.317 & $1,99 \%$ \\
\hline Poulsen et al., 2014 & $2011-2013$ & Northern & RBT card test & 101 & - & 2.561 & $5,50 \%$ \\
\hline $\begin{array}{l}\text { different thesis apud Poulsen } \\
\text { et al., } 2014\end{array}$ & & different regions & serology & & & & [1 - 9,7\%] to [24 - 48\%] \\
\hline
\end{tabular}

\begin{tabular}{|c|c|c|c|c|c|c|c|c|}
\hline \multirow[b]{2}{*}{ Reference } & \multirow[b]{2}{*}{ Year } & \multicolumn{2}{|c|}{ Location } & \multirow{2}{*}{$\begin{array}{l}\text { Test } \\
\text { used }\end{array}$} & \multirow{2}{*}{$\begin{array}{l}\text { Herd } \\
\text { size }^{a}\end{array}$} & \multirow{2}{*}{$\begin{array}{l}\text { No. of } \\
\text { Herds }\end{array}$} & \multirow{2}{*}{$\begin{array}{l}\text { Positive cattle/ } \\
\text { No. of animals }\end{array}$} & \multirow[b]{2}{*}{$(\%)$} \\
\hline & & Province & Canton & & & & & \\
\hline Acosta \& Parreño (16) & 1977 & Tungurahua & Pillaro & SITTO \& CITT' & $\mathrm{NA}^{\mathrm{d}}$ & 20 & $7 / 2132$ & 0.33 \\
\hline \multirow[t]{3}{*}{ Andino-Ashqui (18) } & 2001 & Pichincha & Cayambe & SITT \& CITT & Large & 2 & $5 / 178$ & 2.81 \\
\hline & & Imbabura & Otavalo & & Large & 1 & $24 / 329$ & 7.29 \\
\hline & & Carchi & Espejo & & Large & 2 & $11 / 516$ & 2.13 \\
\hline Salazar \& Cevallos (21) & 2002 & Pichincha & Cayambe & SIT \& CITT & NA & 26 & $14 / 3006$ & 0.47 \\
\hline Cano \& Chulde (22) & 2002 & Pichincha & Mejia & SITT \& CITT & Large & 13 & $152 / 3089$ & 4.92 \\
\hline Burbano \& Léon (20) & 2002 & Carchi & $\begin{array}{l}\text { Espejo, Tulcain } \\
\text { Montufar, Huaca }\end{array}$ & SITT \& CITT & NA & NA & 523011 & 1.73 \\
\hline Bedón \& Verdesoto (19) & 2003 & Imbabura & Ibarra, Otavalo & SITT \& CITT & Large & 13 & $73 / 3005$ & 2.43 \\
\hline Alemán, et al. (17) & 2003 & Tungurahua & Pillaro, Mocha & SITT \& CITT & NA & 24 & $49 / 4012$ & 1.22 \\
\hline Proaho-Pèrez, et al. (14) & 2006 & Pichincha & Mejia & SITT \& CITT & Large & 15 & $26 / 327$ & 7.95 \\
\hline Proaño-Pérez, et al. (15) & 2007 & Pichincha & Mejia & CITT & Large & 13 & $142 / 1644$ & 8.63 \\
\hline Proano-Pérez, et al. (15) & 2008 & Pichincha & Mejia & CITT & Large & 13 & $122 / 1446$ & 8.43 \\
\hline
\end{tabular}

Figure 5 - Prevalence of bovine tuberculosis in dairy cattle according to previous studies - Ecuador - 1977-2008 Source: Peréz et al. (2011) 


\begin{tabular}{|c|c|c|c|c|c|c|c|c|}
\hline \multirow[b]{2}{*}{ Reference } & \multirow[b]{2}{*}{ Year } & \multicolumn{2}{|c|}{ Location } & \multirow{2}{*}{$\begin{array}{l}\text { Test } \\
\text { used }\end{array}$} & \multirow{2}{*}{$\begin{array}{l}\text { Herd } \\
\text { size }\end{array}$} & \multirow{2}{*}{$\begin{array}{l}\text { No. of } \\
\text { Herds }\end{array}$} & \multirow{2}{*}{$\begin{array}{l}\text { Positive cattle/ } \\
\text { No. of animals }\end{array}$} & \multirow[b]{2}{*}{ (\%) } \\
\hline & & Province & Canton & & & & & \\
\hline Canizares (26) & 1977 & Guayas & Guayaquil & SITTP & $\mathrm{NAC}^{\mathrm{C}}$ & NA & $33 / 975$ & 3.38 \\
\hline Maretti (27) & 1981 & Galápagos & San Cristóbal & SITT & NA & NA & $0 / 1000$ & 0.00 \\
\hline Lojan (28) & 1982 & ElOro & Santa Rosa & SIT & NA & NA & $4 / 1465$ & 0.27 \\
\hline Aguirre (29) & 1984 & ElOro & Pasaje & SITT & NA & NA & 0,500 & 0.00 \\
\hline Torres, et al. (30) & 1996 & Santo Domingo & Santo Domingo & SITT & Large & 1 & $21 / 4888$ & 0.43 \\
\hline Gutierrez (31) & 1997 & Guayas & El Triunfo & SITT & $\mathrm{NA}$ & NA & $0 / 300$ & 0.00 \\
\hline Muñoz (32) & 1998 & Los Rios & Ventanas & SITT & NA & NA & $0 / 320$ & 0.00 \\
\hline Villamar (33) & 2000 & Manabi & Pajän & SITT & NA & NA & $0 / 300$ & 0.00 \\
\hline Moncada (34) & 2003 & Guayas & Naranjal & SITT & NA & NA & $14 / 250$ & 5.60 \\
\hline Avellan (35) & 2003 & Guayas & Bucay & SITT & NA & NA & $2 / 200$ & 1.00 \\
\hline Arevalo \& Zamora (36) & 2004 & Santo Domingo & Santo Domingo & SITT \& CITT" & Large & 37 & $20 / 4029$ & 0.50 \\
\hline
\end{tabular}

Figure 6 - Prevalence of bovine tuberculosis in beef cattle according to previous studies - Ecuador - 1977-2008 Source: Peréz et al. (2011)

\section{Peru}

In Peru, studies on the epidemiological situation of bovine brucellosis suggested large regional prevalence differences (Table 8).
Regarding cattle tuberculosis, a national study performed in 1965 reported a high prevalence of animals, which seems to have decreased over the years. The most recent data indicated important regional differences in the prevalence of animals (Table 9).

Table 8 - Prevalence of bovine brucellosis in Peru according to different studies

\begin{tabular}{cccccc}
\hline Author & Year & Location & Test & Tested Animals & \% Positive \\
\hline Huget T. et al., 2005 & & Canta, Lima & RBT + CFT & 486 & $0,21[0,09-0,60]$ \\
Ventocilla G. et al., 2009 & 2004 & Tama-Junín & RBT & 344 & 0 \\
Cardenas, 2000 apud Zavala et al., 2011 & & Tambopata-Madre de Dios & & 2.561 & 5,4 \\
Meza et al., 2010 & 2007 & Puerto Inca & RBT & 3.221 & $0,031[0-0,114]$ \\
Zavala et al., 2011 & 2007 & Codo del Pozuzo, Huánuco & RBT + CFT & 5.439 & $0,02[0-0,06]$ \\
\hline
\end{tabular}

Table 9 - Prevalence of bovine tuberculosis in Peru according to different studies

\begin{tabular}{cccccc}
\hline \multicolumn{1}{c}{ Author } & Year & Location & Test & Tested Animals & \% Positive \\
\hline Castagnino, 1968 apud Sánches; Rosadio, 2002 & 1965 & national & CFT & & 18.1 \\
Senasa, 1999 apud Sánches; Rosadio, 2002 & & Junín & CFT & 1.798 & 0.17 \\
Senasa, 2000 apud Sánches; Rosadio, 2002 & & Cajamarca & CFT & 7.487 & 0.65 \\
Senasa, 2000 apud Sánches; Rosadio, 2002 & & Puno & CFT & 1.901 & 0.21 \\
Senasa, 2000 apud Sánches; Rosadio, 2002 & & Arequipa & CFT & 63.702 & 0.075 \\
Senasa, 2000 apud Sánches; Rosadio, 2002 & & Cusco & CFT & 1.500 & 0 \\
Sánches; Rosadio, 2002 & & Parinacochas & CFT & 461 & 0 \\
Arcelles et al., 2005 & $2001-2002$ & Végueta & CFT & 3.230 & 0.06 \\
Flores et al., 2005 & & Canta, Lima & CFT & 503 & 2.2 \\
\hline
\end{tabular}

\section{Bolivia}

In Bolivia, the studies on the epidemiological situation of brucellosis and tuberculosis in cattle are more frequent in the state of Santa Cruz, possibly because of its importance in cattle farming in the country (Table 10). The data indicated moderate and high prevalence, with relevant regional differences.

Studies on tuberculosis show that the disease occurs in dairy and beef cattle and also suggest important regional differences (Table 11). 
Table 10 - Studies on the epidemiological situation of bovine brucellosis in Bolivia

\begin{tabular}{|c|c|c|c|c|c|c|c|}
\hline \multirow{2}{*}{ Author } & \multirow{2}{*}{ Year } & \multirow{2}{*}{ State } & \multirow{2}{*}{ Province } & \multicolumn{2}{|c|}{ Herds } & \multicolumn{2}{|c|}{ Animals } \\
\hline & & & & Tested & \% Positive & Tested & $\%$ Positive \\
\hline Segovia, R. W. * & 2000 & Tarija & Arce & & & 400 & 0,5 \\
\hline Revollo, Q. J. E. * & 2001 & Cochabamba & Quillacollo & & & & 11,72 \\
\hline Choque, C. M. * & 2001 & Chuquisaca & Azurduy & & & 400 & 0 \\
\hline Sandoval, J. S. * & 2001 & Santa Cruz & Ichilo & & & 1.182 & 1,69 \\
\hline Navarro, G. A. * & 2001 & Santa Cruz & Warnes & & & 2.495 & 3,69 \\
\hline Escobar, F. A. N. * & 2002 & Cochabamba & Chapare-Carrasco & & & 1.250 & 0,3 \\
\hline Zambrana, M.P.W. * & 2003 & Santa Cruz & Chapare & & & 1.098 & 1,64 \\
\hline Manrrique, 2005 & 2005 & Santa Cruz & Andrés Ibáñez, Warnes, Sara, Ñulfo de Chávez & 19 & 36,8 & 2.642 & 2,27 \\
\hline Melean, 2005 & 2005 & Santa Cruz & Andrés Ibáñez, Warnes, Obispo Santiesteban, Sara & 85 & 9,41 & 881 & 1,24 \\
\hline
\end{tabular}

Table 11 - Studies on the epidemiological situation of bovine tuberculosis in Bolivia

\begin{tabular}{cccccc}
\hline Author & Year & Location & Test & Tested Animals & \% Positive \\
\hline Ortiz, 2001 & 1997 & beef cattle from Santa Cruz state & gama interferon & 300 & 0,33 \\
Fedeple apud Marín, 2005 & 1998 & beef cattle from Santa Cruz state & TT & 6.094 & 2,8 \\
Fedeple apud Marín, 2005 & 1999 & dairy cattle from Santa Cruz state & TT & 8.575 & 1,4 \\
Fedeple apud Marín, 2005 & 2000 & dairy cattle from Santa Cruz state & TT & 17.232 & 2,2 \\
Marín, 2005 & 2005 & Cantón Los Chacos, Warnes province, Santa Cruz state & CFT + CCT & 1.691 & 0,83 \\
\hline
\end{tabular}

\section{Paraguay}

In Paraguay, the National Animal Health Service (Senacsa) data on the occurrence of cattle brucellosis, published by Baumgarten (2002), suggested a relatively stable animal prevalence and a decline in the prevalence of infected herds from 1979 to 2000 (Table 12). However, no recent data were found.

Regarding bovine tuberculosis, Kantor and Ritacco (2006) reported that $0.7 \%$ of 11,000 animals tested in 2002 were positive for tuberculin.

Table 12 - Official data on bovine brucellosis in Paraguay

\begin{tabular}{|c|c|c|c|c|c|c|}
\hline \multirow{2}{*}{ Year } & \multicolumn{3}{|c|}{ Animals } & \multicolumn{3}{|c|}{ Herds } \\
\hline & Tested & Positive & (\%) & Tested & Positive & (\%) \\
\hline 1979 & 11.633 & 331 & 2,8 & 151 & 52 & 34,4 \\
\hline 1980 & 62.893 & 988 & 1,6 & 1.719 & 302 & 17,6 \\
\hline 1981 & 91.998 & 1.165 & 1,3 & 2.115 & 450 & 21,3 \\
\hline 1982 & 83.678 & 1.131 & 1,4 & 2.206 & 359 & 16,3 \\
\hline 1983 & 63.292 & 894 & 1,4 & 1.892 & 255 & 13,5 \\
\hline 1984 & 71.082 & 2.529 & 3,6 & 1.741 & 367 & 21,1 \\
\hline 1985 & 49.641 & 2.056 & 4,1 & 1.298 & 374 & 28,8 \\
\hline 1986 & 48.043 & 2.237 & 4,7 & 1.516 & 389 & 25,7 \\
\hline 1987 & 51.350 & 1.721 & 3,4 & 1.586 & 349 & 22 \\
\hline 1988 & 46.221 & 1.222 & 2,6 & 1.761 & 240 & 13,6 \\
\hline 1989 & 34.469 & 794 & 2,3 & 1.414 & 200 & 14,1 \\
\hline 1990 & 44.240 & 1.282 & 2,9 & 2.250 & 224 & 10 \\
\hline 1991 & 63.026 & 1.355 & 2,1 & 3.069 & 285 & 9,3 \\
\hline 1992 & 51.765 & 1.263 & 2,4 & 2.330 & 214 & 9,2 \\
\hline 1993 & 52.825 & 1.835 & 3,5 & 2.533 & 238 & 9,4 \\
\hline 1994 & 78.746 & 2.646 & 3,4 & 4.676 & 336 & 7,2 \\
\hline 1995 & 42.639 & 998 & 2,3 & 1.907 & 172 & 9 \\
\hline 1996 & 58.502 & 1.057 & 1,8 & 3.405 & 177 & 5,2 \\
\hline 1997 & 62.726 & 1.785 & 2,8 & 3.384 & 238 & 7 \\
\hline 1998 & 66.321 & 1.453 & 2,2 & 3.698 & 222 & 6 \\
\hline 1999 & 48.444 & 1.193 & 2,5 & 3.228 & 229 & 7,1 \\
\hline 2000 & 43.637 & 1.786 & 4,1 & 2.839 & 185 & 6,5 \\
\hline Total & 1.227 .171 & 31.721 & & 50.718 & 5.857 & \\
\hline
\end{tabular}

Source: Servicio Nacional de Salud Animal, Paraguay (Senacsa) apud Baumgarten (2002) 


\section{Countries where the epidemiological situation of brucellosis and tuberculosis in cattle is properly characterized}

This group is composed of four countries: Chile, Uruguay, Argentina, and Brazil, which amount to nearly $80 \%$ of the cattle population in South America (Table 1). The detailed situation in each country is described below.

\section{Chile}

On its website, the Chilean Agricultural and Livestock Service (SAG) regularly publishes detailed reports of its program for the eradication of cattle brucellosis. The latest report covered the year 2015 (SAG, 2016). The country is divided into four regions in relation to the epidemiological situation: the area of absence of the disease in the desert region of the North and, going towards the South, the area of sporadic occurrence, the endemic area and the free zone. Chile operates a system of surveillance for the detection of infected herds in order to convert them into free herds based on five components: (1) detection of antibodies in milk; (2) detection of antibodies in the serum of animals in slaughterhouses; (3) serologic tests in animals of cattle fairs; (4) investigation of complaints/notifications of abortion syndrome; and (5) investigation of all positive serological results reported by official and private services.
In 2015, the surveillance activities for the detection of brucellosis-infected herds in Chile involved the detection of antibodies in milk at 3,957 properties and investigation of abortion syndrome in 116 farms. In addition, 128,553 animals were tested in slaughterhouses, 374,117 animals at cattle fairs, and 7,884 animals directly at properties. All efforts resulted in the detection of 31 new infected herds in that year. Figure 7 depicts the performance of the eradication program in Chile from 2006 to 2015.

The SAG performed an extensive data analysis of the occurrence of bovine tuberculosis between 2000 and 2014 , involving $9.4 \%$ of the farms and $23 \%$ of the cattle population of the country in order to characterize the epidemiological situation of the disease. These data, available on the institution website (SAG, 2014), indicated that the disease is primarily more prevalent in regions of Atacama, Coquimbo, Valparaíso, Metropolitan, Biobío, Los Lagos, and Magallanes. In addition, the proportion of infected herds increases according to the size of the herd (Table 13). The result of this study was the foundation for improving the sanitary management of the problem, which was initiated in late 2011 with the launch of the Chilean National Program to combat bovine tuberculosis.

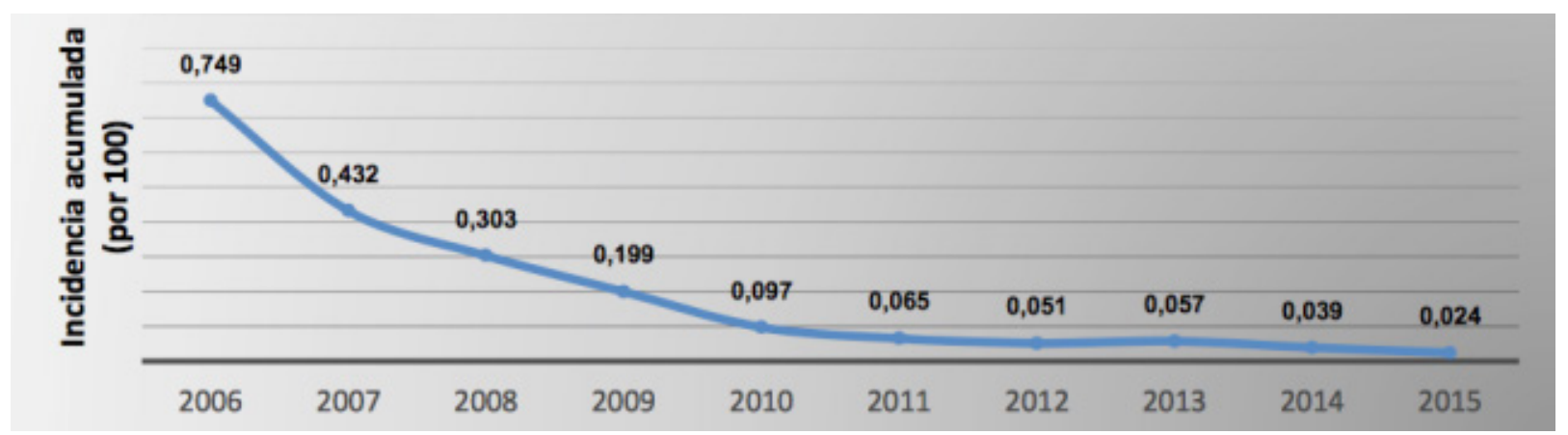

Figure 7 - Incidence of bovine brucellosis-infected herds in Chile from 2006 to 2015 Source: SAG (2016)

Table 13 - Proportion of bovine tuberculosis-infected herds according to the herd size in Chile - 2000-2014

\begin{tabular}{cccc}
\hline Herd Size (N. Cattle) & Tested Herds & Infected Herds & Proportion (\%) \\
\hline$<5$ & 2.596 & 204 & 7,9 \\
5 to 10 & 2.017 & 26 & 1,3 \\
11 to 30 & 3.262 & 137 & 4,2 \\
31 to 100 & 1.983 & 193 & 9,7 \\
101 to 300 & 1.178 & 192 & 16,3 \\
$>300$ & 697 & 207 & 29,7 \\
Total & 11.733 & 959 & 8,2 \\
\hline
\end{tabular}




\section{Uruguay}

The prevalence of infected herds and positive animals for bovine brucellosis in Uruguay was estimated at $0.7 \%$ and $0.04 \%$, respectively (GARIN, 2011). Regarding bovine tuberculosis, the same author reported $0.01 \%$ of carcasses with suggestive lesions being condemned at slaughterhouses.

An interesting report on the situation of brucellosis and tuberculosis in cattle in the country, prepared by the General Directorate of Livestock Services (Dirección General de Servicios Ganaderos), is available on the website of the Uruguayan Ministry of Livestock, Agriculture and Fisheries (URUGUAY, 2015).

Approximately 1.8 million samples were processed in the brucellosis surveillance system routine in 2015 . These led to the identification of 1,188 infected animals and the detection of 99 new infected herds. Figure 8 depicts a historical series of the incidence of infected herds by brucellosis in Uruguay.

Table 14 shows the performance of the surveillance system for bovine tuberculosis, showing the state location of the new infected herds detected in Uruguay in 2015.

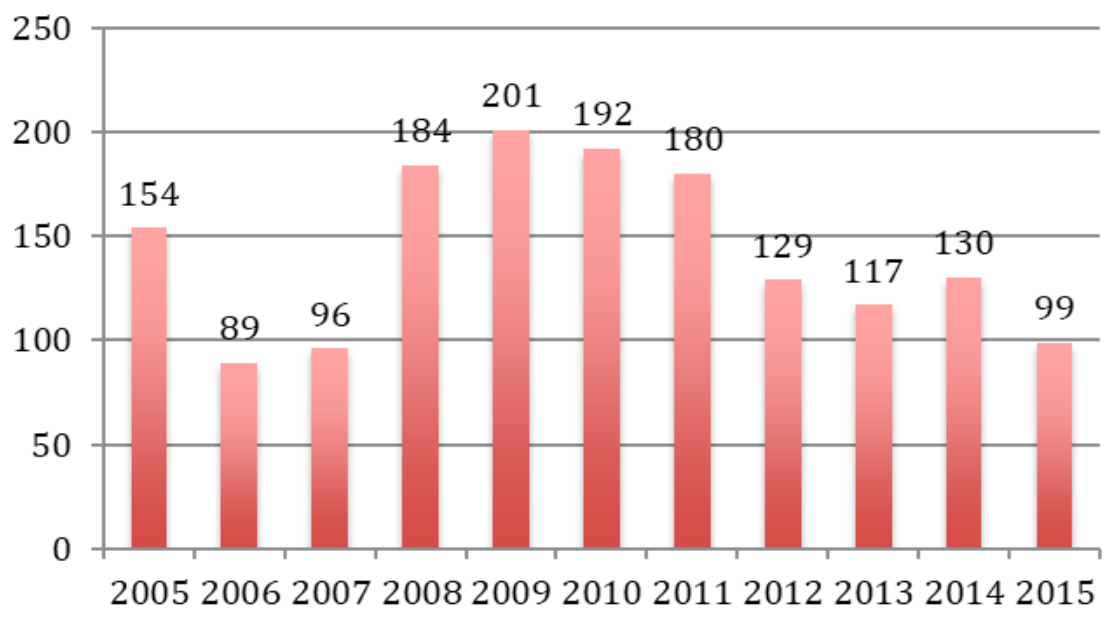

Figure 8 - Incidence of bovine brucellosis-infected herds in Uruguay from 2005 to 2015 Source: Uruguay (2015)

Table 14 - Incidence of bovine tuberculosis-infected herds in Uruguay in 2015 according to states

\begin{tabular}{cc}
\hline State & Number of Infected Herds Detected \\
\hline Colonia & 2 \\
Durazno & 3 \\
Canelones & 2 \\
Florida & 8 \\
Paysandú & 5 \\
Rio Negro & 2 \\
Rocha & 1 \\
San José & 2 \\
Flores & 1 \\
Total & 26 \\
\hline
\end{tabular}

Source: Uruguay (2015)

\section{Argentina}

In 2004, the Official Veterinary Service of Argentina (Senasa) performed a national study on the epidemiological situation of bovine brucellosis. In total, 18,471 adult females aged over 2 years, originating from 1,847 herds, were tested. The prevalence of infected herds was estimated at $12.5 \%$ (10.9-14.0\%) and the prevalence of animals at 2.1\% (1.9-2.4\%)
(SOTA, 2006; AZNAR et al., 2014). Ten years later, Senasa published a report on a second nationwide study $(30,508$ animals from 810 herds were tested), which estimated the prevalence of infected herds at $12.35 \%(10.1-14.6 \%)$ and the prevalence of animals at $0.81 \%$ (0.56-1.05\%) (SENASA, 2014). In conclusion, it was reported that there was a decrease only in the prevalence of animals, from $2.1 \%$ to $0.81 \%$, between 2004 
and 2014, whereas the prevalence of infected herds remained at around 12\%. Table 15 and figure 9 depict data from the 2014 study (SENASA, 2014) indicating a heterogeneity in the prevalence of bovine brucellosis between provinces.

The indicator that Argentina uses to monitor the epidemiological situation of bovine tuberculosis is carcass condemnation at slaughterhouses. Table 16 summarizes the frequency of these condemnations and indicates a decreasing trend since 1970 (TORRES, 2015). Table 17 shows that the disease is mainly concentrated in the provinces of La Pampa, Santa Fe, Buenos Aires and Cordoba (TORRES, 2015).

Table 15 - Prevalence of bovine brucellosis in Argentina, according to provinces

\begin{tabular}{|c|c|c|c|c|c|c|}
\hline \multirow{2}{*}{ Province } & \multicolumn{3}{|c|}{ Animals } & \multicolumn{3}{|c|}{ Herds } \\
\hline & Tested & Positive & Prevalence & Tested & Positive & Prevalence \\
\hline Buenos Aires & 10.265 & 105 & 1,02 & 263 & 39 & 14,83 \\
\hline Chaco & 2.510 & 16 & 0,6 & 69 & 8 & 11,59 \\
\hline Córdoba & 2.651 & 29 & 1,09 & 70 & 9 & 12,86 \\
\hline Corrientes & 2.697 & 12 & 0,4 & 71 & 8 & 11,28 \\
\hline Entre Ríos & 3.617 & 18 & 0,5 & 105 & 13 & 12,38 \\
\hline Formosa & 1.290 & 17 & 1,32 & 37 & 5 & 13,55 \\
\hline La Pampa & 1.709 & 4 & 0,23 & 42 & 3 & 7,14 \\
\hline Salta & 719 & 3 & 0,42 & 23 & 3 & 13,04 \\
\hline San Luis & 1.188 & 2 & 0,17 & 30 & 2 & 6,67 \\
\hline Santa Fe & 2.993 & 37 & 1,24 & 78 & 7 & 8,97 \\
\hline Santiago del Estero & 869 & 3 & 0,35 & 22 & 3 & 13,64 \\
\hline Total & 30.508 & 246 & 0,81 & 810 & 100 & 12,35 \\
\hline
\end{tabular}

Source: Senasa (2014)

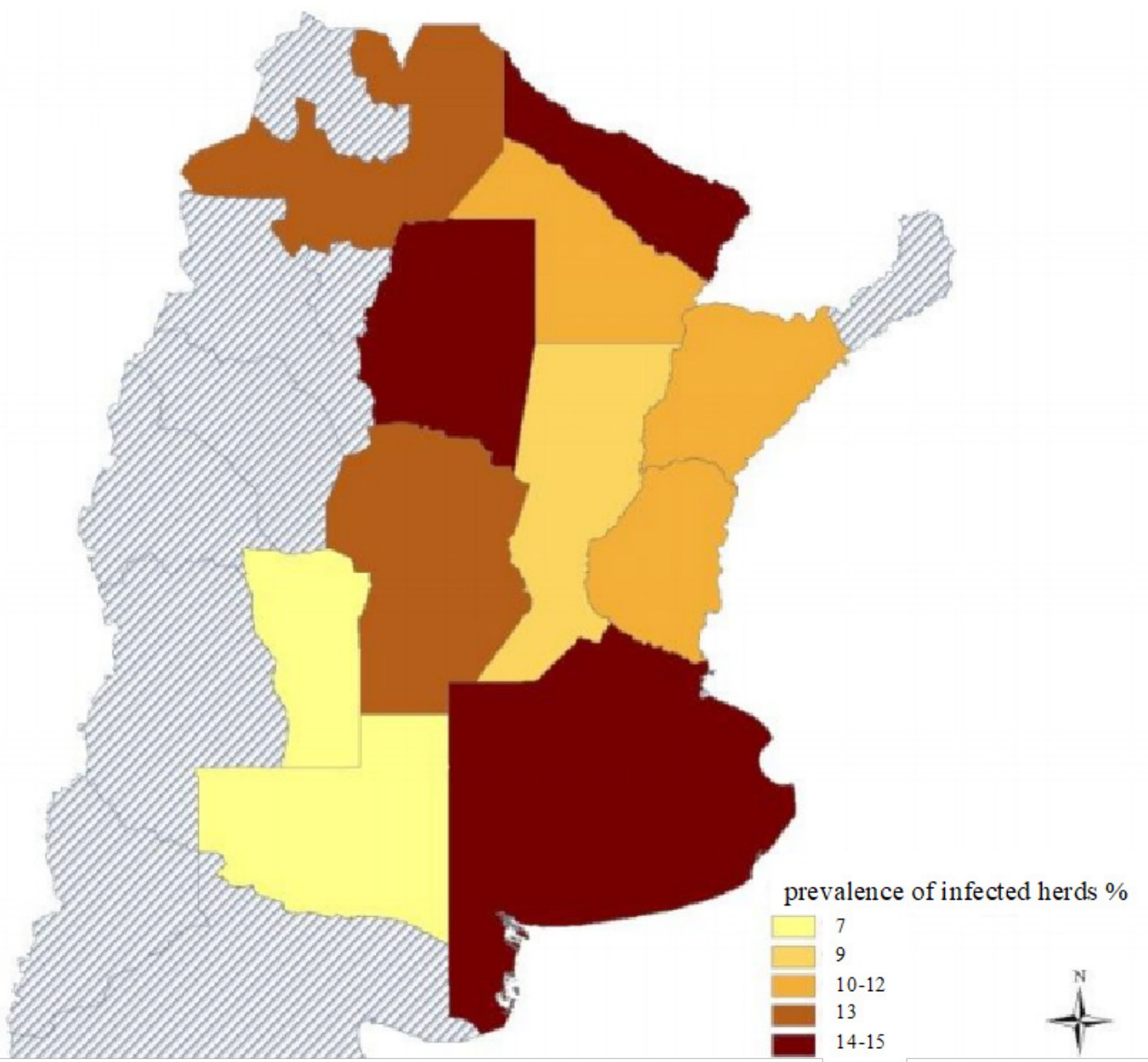

Figure 9 - Prevalence of bovine brucellosis-infected herd in Argentina, according to provinces 
Table 16 - Frequency of cattle condemnation because of tuberculosis in slaughterhouses in Argentina from 1970 to 2015

\begin{tabular}{|c|c|c|c|c|c|c|c|}
\hline Year & Slaughtered & Btb Condemned & $\%$ & Year & Slaughtered & Btb Condemned & $\%$ \\
\hline 1970 & 8.462 .000 & 569.640 & 6,7 & 1993 & 10.283 .000 & 306.322 & 3,1 \\
\hline 1971 & 6.242 .000 & 362.126 & 5,8 & 1994 & 10.266 .393 & 281.873 & 2,7 \\
\hline 1972 & 7.054 .000 & 490.783 & 6,9 & 1995 & 10.100 .398 & 223.688 & 2,2 \\
\hline 1973 & 6.548 .000 & 420.500 & 6,4 & 1996 & 10.550 .624 & 204.004 & 1,9 \\
\hline 1974 & 6.748 .000 & 402.876 & 6 & 1997 & 10.787 .815 & 211.009 & 1,9 \\
\hline 1975 & 8.550 .000 & 424.383 & 4,9 & 1998 & 9.480 .492 & 170.002 & 1,8 \\
\hline 1976 & 9.907 .000 & 603.540 & 6 & 1999 & 10.432 .710 & 162.000 & 1,6 \\
\hline 1977 & 10.69 .000 & 600.815 & 5,6 & 2000 & 10.729 .451 & 146.990 & 1,4 \\
\hline 1978 & 12.277 .000 & 630.839 & 5,1 & 2001 & 9.777 .846 & 135.000 & 1,3 \\
\hline 1979 & 11.733 .000 & 582.357 & 4,9 & 2002 & 9.494 .021 & 133.326 & 1,4 \\
\hline 1980 & 12.277 .000 & 475.889 & 4,5 & 2003 & 10.246 .477 & 124.000 & 1,2 \\
\hline 1981 & 11.733 .000 & 483.023 & 4,2 & 2004 & 12.017 .667 & 147.201 & 1,2 \\
\hline 1982 & 9.557 .000 & 426.727 & 4,5 & 2005 & 12.018 .251 & 140.840 & 1,2 \\
\hline 1983 & 8.751 .000 & 384.358 & 4,4 & 2006 & 11.205 .407 & 114.717 & 1 \\
\hline 1984 & 9.467 .000 & 367.612 & 3,8 & 2007 & 12.375 .477 & 124.998 & 1 \\
\hline 1985 & 10.603 .000 & 400.936 & 3,8 & 2008 & 12.205 .828 & 110.579 & 0,9 \\
\hline 1986 & 10.897 .356 & 425.284 & 3,9 & 2009 & 13.483 .515 & 116.798 & 0,9 \\
\hline 1987 & 10.089 .671 & 440.352 & 4,4 & 2010 & 9.692 .930 & 91.838 & 0,9 \\
\hline 1988 & 9.652 .625 & 298.836 & 4,2 & 2011 & 9.034 .220 & 57.808 & 0,6 \\
\hline 1989 & 9.783 .936 & 365.096 & 3,8 & 2012 & 9.258 .541 & 28.106 & 0,3 \\
\hline 1990 & 10.280 .981 & 475.000 & 3,5 & 2013 & 10.140 .582 & 36.965 & 0,4 \\
\hline 1991 & 10.620 .575 & 339.417 & 3,3 & 2014 & 9.984 .170 & 32.110 & 0,3 \\
\hline 1992 & 10.134 .642 & 317.512 & 3,1 & 2015 & 12.428 .614 & 24.909 & 0,2 \\
\hline
\end{tabular}

Source: Torres (2015)

Table 17 - Frequency of herds with cattle condemned because of tuberculosis in slaughterhouses in Argentina, according to provinces

\begin{tabular}{|c|c|c|c|}
\hline Provinces & Total of Herds & Infected Herds & $\%$ \\
\hline Buenos Aires & 60.322 & 2.268 & 3.7 \\
\hline Catamarca & 5.322 & 5 & 0.09 \\
\hline Chaco & 30.981 & 386 & 1.2 \\
\hline Chubut & 2.717 & 0 & 0 \\
\hline Cordoba & 24.776 & 907 & 3.6 \\
\hline Corrientes & 28.704 & 108 & 0.4 \\
\hline Entrerios & 37.461 & 392 & 1.04 \\
\hline Formosa & 16.448 & 137 & 0.8 \\
\hline Jujuy & 3.571 & 6 & 0.2 \\
\hline La Pampa & 10.646 & 1516 & 14.2 \\
\hline La Rioja & 3.791 & 1 & 0.02 \\
\hline Mendoza & 4.237 & 11 & 0.3 \\
\hline Misiones & 7.879 & 1 & 0.01 \\
\hline Neuquen & 2.680 & 0 & 0 \\
\hline Rio Negro & 4.442 & 29 & 0.6 \\
\hline Salta & 15.026 & 32 & 0.21 \\
\hline San Juan & 758 & 0 & 0 \\
\hline San Luis & 9.330 & 79 & 0.8 \\
\hline Santa Cruz & 425 & 1 & 0.2 \\
\hline Santa Fe & 31.461 & 1751 & 5.6 \\
\hline Santiago del Estero & 14.863 & 131 & 0.9 \\
\hline Tierra Fuego & 64 & 0 & 0 \\
\hline Tucuman & 3.552 & 16 & 0.5 \\
\hline Total & 319.721 & 7.777 & 2.4 \\
\hline
\end{tabular}




\section{Brazil}

Brazil launched a national program of control and eradication of brucellosis and tuberculosis in cattle in 2001. Ever since, the country has been investigating the epidemiological situation of both diseases to define strategies and manage processes (LAGE et al., 2006). These investigations are performed through cross-sectional studies based on a partnership between the Department of Animal Health of the Ministry of Agriculture, Livestock and Food Supply, the official veterinary services of the states, and the Collaborating Center for Animal Health of the College of Veterinary Medicine and Animal Science of the University of São Paulo.

Regarding bovine brucellosis, 18 states have been investigated to date, which amount to $85 \%$ of the cattle population in Brazil, indicating significant differences within states (regional differences) and between states. The results indicated a prevalence of infected herds ranging from $0.32 \%$ (state of Santa Catarina) to $41.5 \%$ (state of Mato Grosso do Sul) (ALVESetal.,2009; AZEVEDOetal.,2009; CHATEetal.,2009;
DIAS et al., 2009a, 2009b; GONÇALVES et al., 2009a, 2009b; KLEIN-GUNNEWIEK et al., 2009; MARVULO et al., 2009; NEGREIROS et al., 2009; OGATA et al., 2009; ROCHA et al., 2009; SIKUSAWA et al., 2009; SILVA et al., 2009; VILLAR et al., 2009; BORBA et al., 2013; ALMEIDA et al., 2016; CLEMENTINO et al., 2016). Approximately ten years after the first study, eight states repeated the same investigation. Of these, seven studies aimed at verifying the effectiveness of their vaccination programs (ANZAI et al., 2016; BARDDAL et al., 2016; BAUMGARTEN et al., 2016; DIAS et al., 2016a; INLAMEA et al., 2016; LEAL FILHO et al., 2016; OLIVEIRA et al., 2016; SILVA et al., 2016b). In only four of these studies was it possible to verify the reduction of the disease prevalence following well-structured vaccination programs (Table 18).

Figure 10 depicts the results of the first studies conducted by the states, and figure 11 depicts the latest situation, including the decrease in prevalence achieved by four states because of effective implemented vaccination programs.

Table 18 - Reduction of the prevalence of bovine brucellosis-infected herds in Brazilian states as a consequence of effective vaccination programs

\begin{tabular}{|c|c|c|c|c|c|c|}
\hline \multirow{2}{*}{ State } & \multicolumn{3}{|c|}{ First Study } & \multicolumn{3}{|c|}{ Second Study } \\
\hline & Year & Prevalence (\%) & IC95\% (\%) & Year & Prevalence (\%) & IC95\% (\%) \\
\hline Mato Grosso do Sul & 1998 & 41,5 & $36,5-44,7$ & 2009 & 30,6 & $27,4-34,0$ \\
\hline Minas Gerais & 2002 & 6,04 & $4,98-7,10$ & 2011 & 3,59 & $2,76-4,42$ \\
\hline Mato Grosso & 2003 & 41,2 & $38,0-44,4$ & 2014 & 24 & $21,3-26,8$ \\
\hline Rondônia & 2004 & 35,18 & $32,09-38,36$ & 2014 & 12,3 & $10,3-14,6$ \\
\hline
\end{tabular}

Source: Ferreira Neto et al. (2016)

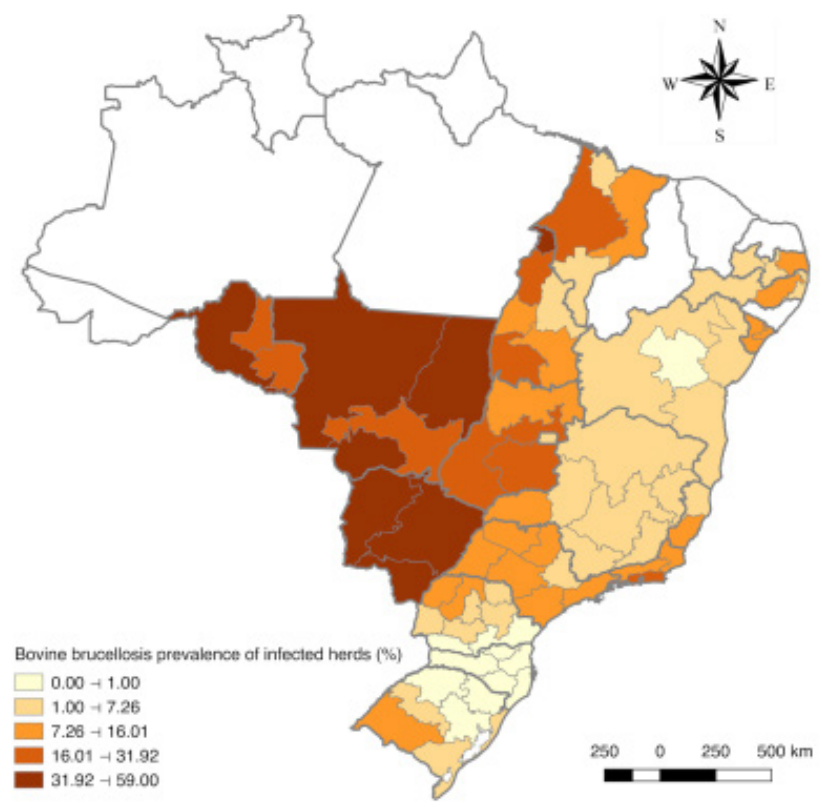

Figure 10 - First studies on the prevalence of bovine brucellosis-infected herds in Brazil

Source: Ferreira Neto et al. (2016) 


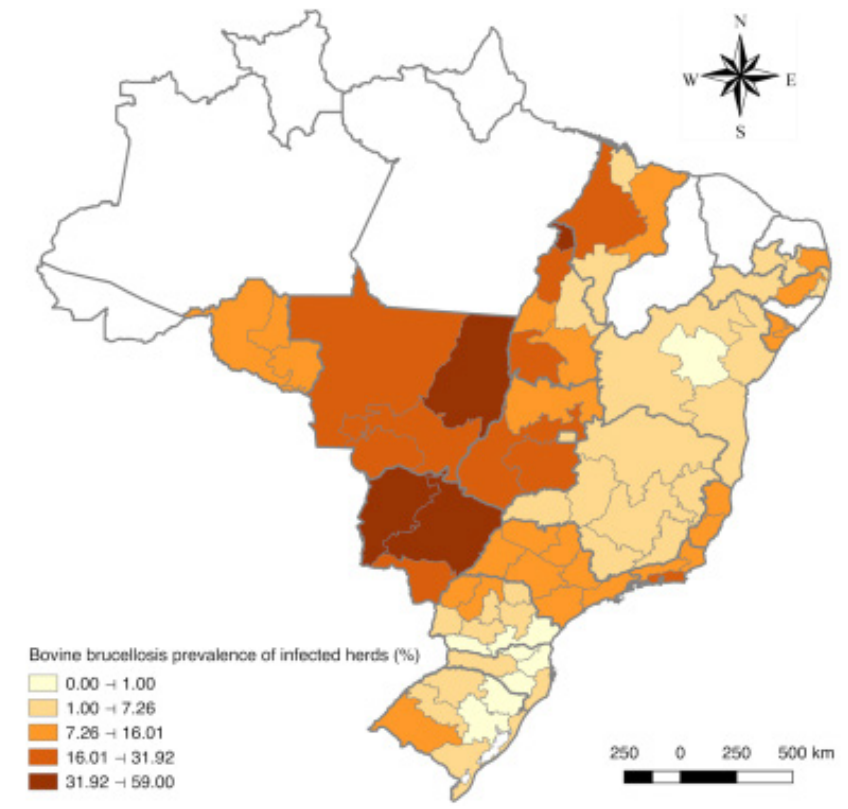

Figure 11 - Latest studies on the prevalence of herds infected with bovine brucellosis carried out in Brazilian states, showing the effect of the vaccination programs lowering the prevalence in some regions respect Figure 10

Source: Ferreira Neto et al. (2016)

In Brazil, the epidemiological situation of bovine tuberculosis is very well characterized in $75 \%$ of the cattle population. Transversal studies indicated a prevalence of infected herds varying from $0.36 \%$ (Distrito Federal) to $9 \%$ (state of São Paulo), and a prevalence of animals ranging from $0.035 \%$ to $1.3 \%$ in the same states. Furthermore, the disease was more prevalent in high-production dairy farms and the major risk factor was the introduction of animals without testing. Figure
12 indicates a higher prevalence in the state of Espírito Santo, north of São Paulo, south of Minas Gerais, and southern Goiás, coinciding with the milk-producing belt in Brazil (BAHIENSE et al., 2016; BARBIERI et al., 2016; DIAS et al., 2016b; FERREIRA NETO et al., 2016; GALVIS et al., 2016; GUEDES et al., 2016; LIMA et al., 2016; NÉSPOLI et al., 2016; QUEIROZ et al., 2016; RIBEIRO et al., 2016; ROCHA et al., 2016; SILVA et al., 2016a; VELOSO et al., 2016; VENDRAME et al., 2016).

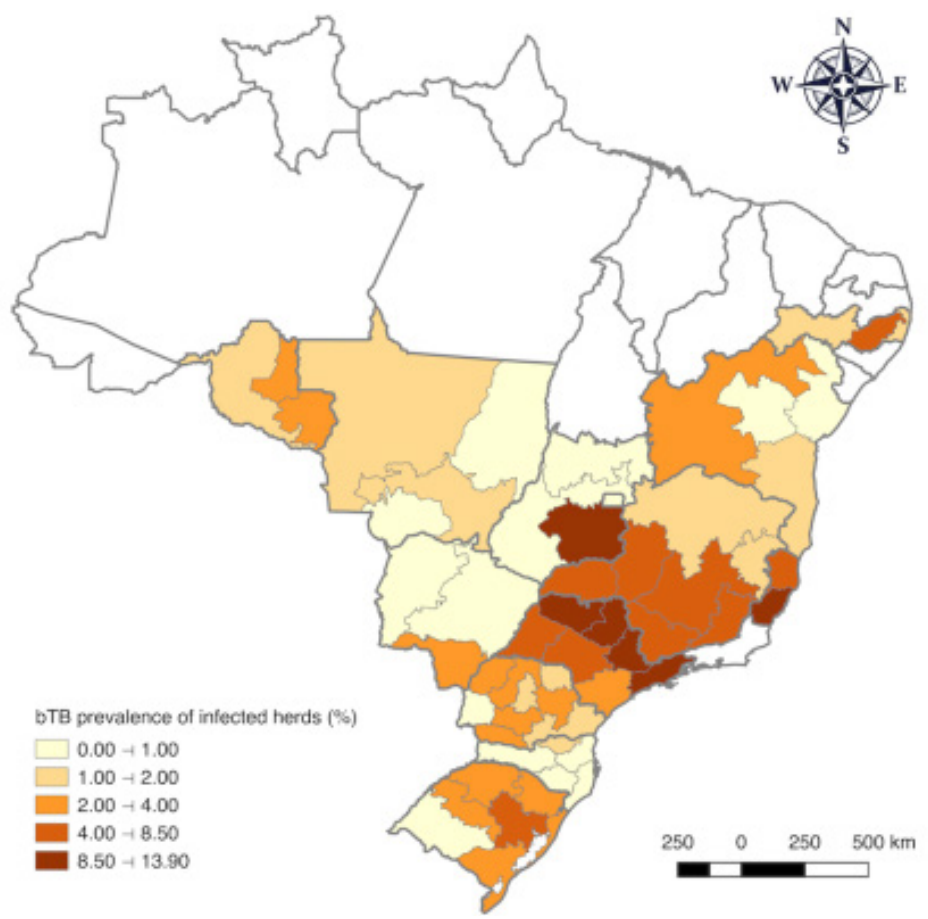

Figure 12 - Prevalence of bovine tuberculosis-infected herds in Brazil Source: Ferreira Neto et al. (2016) 


\section{Conclusions}

For the epidemiological situation of both diseases, the main conclusions were condensed into topics.

Brucellosis:

- the situation is heterogeneous among countries and most of them also feature internal heterogeneities;

- Chile and Uruguay are running eradication strategies. The countries have very low prevalence and the program information is well documented and easily accessible;

- Argentina has a moderate prevalence and information about the program is available;

- Colombia is developing a process of accreditation of free herds and free areas, and maintains updated information on the official websites, but the prevalence of the disease in the country is not well characterized;

- the epidemiological situation of the disease in Brazil is well described in $85 \%$ of cattle population, though it is very uneven amongst states and regions, and vaccination programs implemented by states have produced encouraging results;

- in other countries, the domestic situation is also heterogeneous and national studies are necessary to properly plan the disease control and eradication.

Tuberculosis:

- the disease is associated with larger intensive dairy farms and the epidemiological situation among countries is quite different;

- Uruguay presents a very low prevalence and is running the eradication phase, with welldocumented and available information;

- Chile and Argentina are running surveillance systems, but the prevalence is still high, especially in Chile and in certain regions of Argentina;

- Colombia is developing a process of accreditation of free herds, but the disease situation is not properly characterized in the country;

- the epidemiological situation of the disease in Brazil is well described in $75 \%$ of cattle population, with very low prevalence in beef production regions and higher in dairy basins;

- in other countries, the internal situation seems to be quite heterogeneous and national studies are essential to properly plan the disease control and eradication.

\section{Final remarks}

The information on the epidemiological situation of brucellosis and tuberculosis in cattle has been presented herein because it is vital to successful control and eradication programs. Countries that do not generate high-quality quantitative epidemiological data on these diseases have serious limitations for outlining strategies. Moreover, they are unable to perform the management of processes, which is essential to measure the effectiveness of actions implemented so that they can be modified or corrected whenever necessary.

These data, basically represented by the prevalence of infected herds and animals, may be obtained by well-planned cross-sectional studies in order to capture regional heterogeneity, or by data generated from well-structured surveillance system routines. It must be pointed out that the prevalence of infected herds is the most relevant indicator, as the herds, properties, or farms, but not the animal, are the epidemiological units of interest to either control or eradicate brucellosis or tuberculosis in cattle.

Although bovine carcass condemnation because of tuberculosis at slaughterhouses is often used as an indicator of prevalence, it must be highlighted that it would be important to confirm the etiology the lesion in laboratory, preferably by isolation and identification of the Mycobacterium bovis (bTb), considering that the positive predictive value of the macroscopic inspection for the diagnosis of bovine tuberculosis tends to be low in accordance with the low prevalence that the disease usually presents in areas where extensive farming is predominant (GRISI-FILHO et al., 2011). Furthermore, illegal slaughtering represents a problem for the quantification of tuberculosis in cattle population, because it is conducted without official inspection and subsequent registration of the number of slaughtered and bTb condemned animals.

Regarding bovine brucellosis, which provides vaccines to reduce the prevalence at a low cost, the vaccination coverage is frequently used as an indicator of performance of the program. However, calculating it is not trivial, considering the difficulty of accurately estimating the vaccinable population, as well as the vaccinated population (KURODA et al., 2016). A correct estimate of the vaccinable population depends on high-quality cadastral data, and the vaccinated population is often overrated because fraud in the issuance of certificates of vaccination is not unusual. Thus, well planned cross-sectional studies, performed 
at strategic moments, are an efficient way to verify if the vaccination produced the expected result, i.e., the decrease in prevalence.

The number of properties certified as free is also often used as a program performance indicator. Nonetheless, it is overrated as a management tool because it does not quantify the prevalence or incidence of infected herds, i.e., it does not provide knowledge on whether the implemented strategies result in a decrease in infected properties. Aggressive strategies of testing and euthanasia, which form the foundation of the accreditation of free herds, make much more sense when implemented in infected herds

\section{References}

AGUAYO, M. D. Z.; RUANO, M. P. Seroprevalencia de brucelosis en ganado bovino y en humanos vinculados a la ganadería bovina en las zonas norte y centro de la provincia Manabí, Ecuador. Revista de Salud Animal, v. 37, n. 3, p. 164-172, 2015.

ALMEIDA, E. C.; FREITAS, A. A.; PONTUAL, K. A. Q.; SOUZA, M. M. A.; AMAKU, M.;DIAS, R. A.; FERREIRA, F.; TELLES, E. O.; HEINEMANN, M. B.; GONÇALVES, V. S. P.; EVÊNCIO NETO, J.; MARVULO, M. F. V.; GRISI-FILHO, J. H. H.; FERREIRA NETO, J. S.; SILVA, J. C. R. Prevalence and associated risk factors for bovine brucellosis in the state of Pernambuco, Brazil. Semina: Ciências Agrárias, v. 37, n. 5, p. 3413-3424, 2016. Supplement 2. doi: 10.5433/1679-0359.2016v37n5Supl2p3601.

ALVES, A. J. S.; GONÇALVES, V. P. S.; FIGUEIREDO, V. C. F.; LOBO, J. R.; BAHIENSE, L.; AMAKU, M.; FERNANDO, F.; FERREIRA NETO, J. S.; DIAS, R. A. Situação epidemiológica da brucelose bovina no Estado da Bahia. Arquivo Brasileiro de Medicina Veterinária e Zootecnia, v. 61, p. 6-13, 2009. Supplement 1. doi: 10.1590/ S0102-09352009000700002.

ANZAI, E. K.; COSTA, D.; SAID, A. L. P. R.; GRISIFILHO, J. H. H.; AMAKU, M.; DIAS, R. A.; FERREIRA, F.; GALVIS, J. O. A.; GONÇALVES, V. S. P.; HEINEMANN, M. B.; TELLES, E. O.; FERREIRA NETO, J. S. An update on the epidemiological situation of bovine brucellosis in the state of Espírito Santo, Brazil. Semina: Ciências Agrárias, v. 37, n. 5, p. 3437-3448, 2016. Supplement 2. doi: 10.5433/1679-0359.2016v37n5Supl2p3437. detected by surveillance systems, notably when fully or partially funded by the state.

To conclude, it is only possible to manage the programs for the control and eradication of brucellosis and tuberculosis in cattle if there are well defined and efficient mechanisms to quantify them in populations, using appropriate methodologies to estimate the prevalence of infected herds.

\section{Acknowledgments}

The author thanks Dr. Cássia Yumi Ikuta for her assistance with the bibliographic research.

ARCELLES, P. M.; DELGADO, C. A.; ALZAMORA, P. C.; MANCHEGO, S. A.; GAVIDIA, C. C. Prevalencia de tuberculosis bovina en el distrito de Végueta, Huaura. Revista de Investigaciones Veterinarias del Perú, v. 16, n. 2, p. 154-157, 2005. doi: 10.15381/rivep.v16i2.1555.

ARGENTINA. Servicio Nacional de Sanidad y Calidad Agroalimentaria. Informe del muestreo para determinación de prevalencias de brucelosis bovina en la zona de mayor producción bovina en la Republica Argentina: año 2014. Buenos Aires: Senasa, 2014. 21 p. Available from: <https:// goo.gl/DYjy2j>. Viewed: 16 Aug. 2017

ARICAPA, H. J.; JARAMILLO, A.; AMAYA, C.; CASTRILLÓN, A.; LONDOÑO, L.; LARGO, J.; PÉREZ, J. E.; ALZATE, E.; BUITRAGO, F.; FERIS, J.; GALLEGO, M.; MURILLO, J. M.; HURTADO, J. M.; SÁNCHEZ, F.; MARTÍNEZ, A.; HERNÁNDEZ, J. F.; OROZCO, J. Prevalence of bovine, equine and human brucellosis in Caldas-Colombia-South America. Biosalud, v. 7, n. 1, p. 75-87, 2008.

AZEVEDO, S. S.; FERREIRA NETO, J. S.; DIAS, R. A.; FERREIRA, F.; AMAKU, M.; FIGUEIREDO, V. C. F.; LOBO, J. R.; GONÇALVES, V. S. P.; SOUZA, A. C.; VASCONCELLOS, S. A. Situação epidemiológica da brucelose bovina no Estado do Espírito Santo. Arquivo Brasileiro de Medicina Veterinária e Zootecnia, v. 61, p. 19-26, 2009. Supplement 1. doi: 10.1590/S0102-09352009000700004.

AZNAR, M. N.; SAMARTINO, L. E.; HUMBLET, M. F.; SAEGERMAN, C. Bovine Brucellosis in Argentina 
and bordering countries: update. Transboundary and Emerging Diseases, v. 61, n. 2, p. 121-133, 2014. doi: 10.1111/tbed.12018.

BAHIENSE, L.; ÁVILA, L. N.; BAVIA, M. E.; AMAKU, M.; DIAS, R. A.; GRISI-FILHO, J. H. H.; FERREIRA, F.; TELLES, E. O.; GONÇALVES, V. S. P.; HEINEMANN, M. B.; FERREIRA NETO, J. S. Prevalence and risk factors for bovine tuberculosis in the State of Bahia, Brazil. Semina: Ciências Agrárias, v. 37, n. 5, p. 3549-3560, 2016, Supplement 2. doi: 10.5433/1679-0359.2016v37n5Supl2p3549.

BARBIERI, J. M.; OLIVEIRA, L. F.; DORNELES, E. M. S.; MOTA, A. L. A. A.; GONÇALVES, V. S. P.; MALUF, P. P.; FERREIRA NETO, J. S.; FERREIRA, F.; DIAS, R. A.; TELLES, E. O.; GRISI-FILHO, J. H. H.; HEINEMANN, M. B.; AMAKU, M.; LAGE, A. P. Epidemiological status of bovine tuberculosis in the state of Minas Gerais, Brazil, 2013. Semina: Ciências Agrárias, v. 37, n. 5, p. 3531-3548, 2016. Supplement 2. doi: 10.5433/1679-0359.2016v37n5Supl2p3531.

BARDDAL, J. E. I.; SANTOS, J. C. Q.; LOPES, I. F.; FERREIRA NETO, J. S.; FERREIRA, F.; AMAKU, M.; DIAS, R. A.; TELLES, E. O.; GRISI-FILHO, J. H. H.; HEINEMANN, M. B.; GONÇALVES, V. S. P.; AGUIAR, D. M.Effect of vaccination in lowering the prevalence of bovine brucellosis in the state of Mato Grosso, Brazil. Semina: Ciências Agrárias, v. 37, n. 5, p. 3479-3492, 2016. Supplement 2. doi: 10.5433/1679-0359.2016v37n5Supl2p3479.

BAUMGARTEN, D. Brucellosis: a short review of the disease situation in Paraguay. Veterinary Microbiology, v. 90, n. 1-4, p. 63-69, 2002. doi: 10.1016/S0378-1135(02)00246-8.

BAUMGARTEN, K. D.; VELOSO, F. P.; GRISI-FILHO, J. H. H.; FERREIRA, F.; AMAKU, M.; DIAS, R. A.; TELLES, E. O.; HEINEMANN, M. B.; GONÇALVES, V. S.; FERREIRA NETO, J.S. Prevalence and risk factors for bovine brucellosis in the State of Santa Catarina, Brazil. Semina: Ciências Agrárias, v. 37, n. 5, p. 3425-3436, 2016. Supplement 2. doi: 10.5433/1679-0359.2016v37n5Supl2p3425.

BORBA, M. R.; STEVENSON, M. A.; GONÇALVES, V. S. P.; FERREIRA NETO, J. S.; FERREIRA, F.; AMAKU, M.; TELLES, E. O.; SANTANA, S. S.; FERREIRA, J. C. A.; LOBO, J. R.; FIGUEIREDO, V. C. F.; DIAS, R. A. Prevalence and risk-mapping of bovine brucellosis in Maranhão state, Brazil. Preventive Veterinary Medicine, v. 110, n. 2, p. 169-176, 2013. doi: 10.1016/j.prevetmed.2012.11.013.

CLEMENTINO, I. J.; DIAS, R. A.; AMAKU, M.; FERREIRA, F.; TELLES, E. O.; HEINEMANN, M. B.; GONÇALVES, V. S. P.; GRISI-FILHO, J. H. H.; FERREIRA NETO, J. S.; ALVES, C. J.; SANTOS, C. S. A. B.; AZEVEDO, S. S. Epidemiological situation of bovine brucellosis in the state of Paraiba, Brazil. Semina: Ciências Agrárias, v. 37, n. 5, p. 3403-3412, 2016. doi: 10.5433/1679-0359.2016v37n5Supl2p3403.

COLOMBIA. Ministerio de Agricultura y Desarollo Rural. Instituto Colombiano Agropecuario. Campaña de Erradicación Tuberculosis Bovina. ICA, 2010, Bogotá. Available from: <https://goo.gl/i3DZ6k>. Viewed: 6 June 2018.

COLOMBIA. Ministerio de Agricultura y Desarollo Rural. Instituto Colombiano Agropecuario. Avance en la Erradicación de la Brucelosis en Colombia. ICA, 2016, Bogotá. Available from: <https://goo.gl/zqxBbN>. Viewed: 6 June 2018.

COOK, R. World Cattle Inventory: ranking of countries (FAO). Drovers, Lenexa, 2015. Available from: <https:// goo.gl/GAwywJ>. Viewed: 3 Aug. 2017.

CHATE, S. C.; DIAS, R. A.; AMAKU, M.; FERREIRA, F.; MORAES, G. M.; COSTA NETO, A. A.; MONTEIRO, L. A. R. C.; LOBO, J. R.; FIGUEIREDO, V. C. F.; GONÇALVES, V. S. P.; FERREIRA NETO, J. S. Situação epidemiológica da brucelose bovina no Estado do Mato Grosso do Sul. Arquivo Brasileiro de Medicina Veterinária e Zootecnia, v. 61 , p. 46-55, 2009. Supplement 1. doi: 10.1590/S010209352009000700007.

CHILE. Ministerio de Agricultura. Servicio Agricola y Ganadero. Ocurrencia de la tuberculosis bovina en Chile (2000-2014). Agosto, 2014. Available from: <https://goo. gl/D2HUUG>. Viewed: 14 Aug. 2017.

CHILE. Ministerio de Agricultura. Servicio Agricola y Ganadero. Resultados del Programa Nacional de Erradicación de Brucelosis Bovina año 2015. Marzo, 2016. Available from: <https://goo.gl/BB1h1T >. Viewed: 14 Aug. 2017. 
D’POOL, G.; PIRELA, S. R.; TORRES, T.; PÉREZ, M.; GARCÍA, A.; CASTEJÓN, O.; ROJAS, N. Prevalencia de brucelosis bovina mediante Elisa competitivo en el municipio La Cañada de Urdaneta, estado Zulia, Venezuela. Revista Científica, v. 14, n. 2, p. 168-176, 2004.

DIAS, J. A.; MÜLLER, E. E.; DIAS, R. A.; FREITAS, J. C.; AMAKU, M.; FERREIRA, F.; SILVA, M. C. P.; LOBO, J. R.; FIGUEIREDO, V. C. F.; GONÇALVES, V.S. P.; FERREIRA NETO, J. S. Situação epidemiológica da brucelose bovina no Estado do Paraná. Arquivo Brasileiro de Medicina Veterinária e Zootecnia, v. 61, p. 66-76, 2009a. Supplement 1. doi: 10.1590/S0102-09352009000700009.

DIAS, R. A.; BELCHIOR, A. P. C.; FERREIRA, R. S.; GONÇALVES, R. C.; BARÃO, R. S. C.; SOUSA, P. R.; SANTOS, A. M.A.; AMAKU, M.; FERREIRA, F.; TELLES, E. O.; GRISI-FILHO, J. H. H.; HEINEMANN, M. B.; GONÇALVES, V.S. P.; FERREIRA NETO, J. S. Controlling bovine brucellosis in the state of São Paulo, Brazil: results after ten years of a vaccination program. Semina: Ciências Agrárias, v. 37, n. 5, p. 3505-3518, 2016a. Supplement 2. doi: 10.5433/1679-0359.2016v37n5Supl2p3505.

DIAS, R. A.; GONÇALVES, V. S. P.; FIGUEIREDO, V. C. F.; LOBO, J. R.; LIMA, Z. M. B.; PAULIN, L. M. S.; GUNNEWIEK, M. F. K.; AMAKU, M.; FERREIRA NETO, J. S.; FERREIRA, F. Situação epidemiológica da brucelose bovina no Estado de São Paulo. Arquivo Brasileiro de Medicina Veterinária e Zootecnia, v. 61, p. 118-125, 2009b. Supplement 1. doi: 10.1590/S010209352009000700015.

DIAS, R. A.; STANOJLOVIC, F. M. U.; BELCHIOR, A. P. C.; FERREIRA, R. S.; GONÇALVES, R. C.; AGUIAR, R. S. C. B.; SOUSA, P. R.; SANTOS, A. M. A.; AMAKU, M.; FERREIRA, F.; TELLES, E. O.; GRISI-FILHO, J. H. H.; GONÇALVES, V. S. P.; HEINEMANN, M. B.; FERREIRA NETO, J. S. Prevalence and risk factors for bovine tuberculosis in the state of São Paulo, Brazil. Semina: Ciências Agrárias, v.37,n.5,p.3673-3684,2016b.Supplement 2. doi: 10.5433/1679-0359.2016v37n5Supl2p3673.

FERREIRA NETO, J. S.; SILVEIRA, G. B.; ROSA, B. M.; GONÇALVES, V. S. P.; GRISI-FILHO, J. H. H.; AMAKU, M.; DIAS, R. A.; FERREIRA, F.; HEINEMANN, M. B.; TELLES, E. O.; LAGE, A. P. Analysis of 15 years of the
National Program for the Control and Eradication of Animal Brucellosis and Tuberculosis, Brazil. Semina: Ciências Agrárias, v. 37, n. 5, p. 3385-3402, 2016. Supplement 2. doi: 10.5433/1679-0359.2016v37n5Supl2p3385.

FLORES, C. F.; DELGADO, C. A.; GONZÁLEZ, Z. A.; RIVERA, G. H. Determinación de la presencia de tuberculosis bovina en la provincia de Canta, Lima. Revista de Investigaciones Veterinarias del Perú, v. 16, n. 1, p. 65-70, 2005. doi: 10.15381/rivep.v16i1.1539.

GALVIS, J. O. A.; GRISI-FILHO, J. H. H.; COSTA, D.; SAID, A. L. P. R.; AMAKU, M.; DIAS, R. A.; FERREIRA, F.; GONÇALVES, V. S. P.; HEINEMANN, M. B.; TELLES, E. O.; FERREIRA NETO, J. S. Epidemiologic characterization of bovine tuberculosis in the state of Espírito Santo, Brazil. Semina: Ciências Agrárias, v. 37, n. 5, p. 3567-3578, 2016. Supplement 2. doi: 10.5433/1679-0359.2016v37n5Supl2p3567.

GARÍN, A. Program of control/eradication of bovine brucellosis in Uruguay. In: ANNUAL BRUCELLOSIS RESEARCH CONFERENCE, 64., 2011, Buenos Aires. Proceedings... 2011, Buenos Aires: Associación Argentina de Microbiología, 2011. p. 18-19.

GIRALDO, J. L. M.; HOYOS, J. A. C.; GARCÍA, I. W.; ABELEDO, M. A. Prevalencia de anticuerpos a Brucella abortus,Leptospira sp. y Neospora caninum en hatos bovinos y bubalinos en el Departamento de Caquetá, Colombia. Revista de Salud Animal, v. 36, n. 2, p. 80-89, 2014.

GONÇALVES, V. S. P.; DELPHINO, M. K. V. C.; DIAS, R. A.; FERREIRA, F.; AMAKU, M.; FERREIRA NETO, J. S.; PORTO, T. B.; ALVES, C. M.; FIGUEIREDO, V. C. F.; LOBO, J. R. Situação epidemiológica da brucelose bovina no Estado de Minas Gerais. Arquivo Brasileiro de Medicina Veterinária e Zootecnia, v. 61, p. 5-45, 2009a. Supplement 1. doi: 10.1590/S0102-09352009000700006.

GONÇALVES, V. S. P.; RIBEIRO, L. A.; CALDAS, R. A.; FRANCISCO, P. F. C.; DIAS, R. A.; FERREIRA, F.; AMAKU, M.; FERREIRA NETO, J. S.; FIGUEIREDO, V. C. F.; LOBO, J. R.; BORGES, J. R. J. Situação epidemiológica da brucelose bovina no Distrito Federal. Arquivo Brasileiro de Medicina Veterinária e Zootecnia, 
v. 61, p. 14-18, 2009b. Supplement 1. doi: 10.1590/S010209352009000700003.

GRISI-FILHO, J. H. H.; ROSALES, C. A. R.; FERREIRA, F.; AMAKU, M.; DIAS, R. A.; FERREIRA NETO, J. S. Epidemiological analysis of the bovine tuberculosis condemnations in abattoirs in the state of São Paulo, Brazil. Arquivos do Instituto Biológico, v. 78, n. 2, p. 175-181, 2011.

GUEDES, I. B.; BOTTENE, I. F. N.; MONTEIRO, L. A. R. C.; LEAL FILHO, J. M.; HEINEMANN, M. B.; AMAKU, M.; GRISI-FILHO, J. H. H.; DIAS, R. A.; FERREIRA, F.; TELLES, E. O.; GONÇALVES, V. S. P.; FERREIRA NETO, J. S. Prevalence and risk factors for bovine tuberculosis in the state of Mato Grosso do Sul, Brazil. Semina: Ciências Agrárias, v. 37, n. 5, p. 3579-3588, 2016. Supplement 2. doi: 10.5433/1679-0359.2016v37n5Supl2p3579.

HugueT, T. C.; DELGADO, C. A.; CALLE, E. S.; GONZÁlEZ, Z. A. Cuantificación de Brucella sp. en bovinos de la provincia de Canta, Lima. Revista de Investigaciones Veterinarias del Perú, v. 16, n. 2, p. 158-162, 2005. doi: 10.15381/rivep.v16i2.1558.

INLAMEA, O. F.; ROCHA, A. B.; FERREIRA, F.; GRISIFILHO,J.H.H.;HEINEMANN, M.B.;DIAS, R. A.;TELLES, E. O.; GONÇALVES, V. S. P.; AMAKU, M.; FERREIRA NETO, J. S. Effect of vaccination in lowering bovine brucellosis in the state of Rondônia, Brazil. Semina: Ciências Agrárias, v. 37, n. 5, p. 3493-3506, 2016. Supplement 2. doi: 10.5433/1679-0359.2016v37n5Supl2p3493.

KANTOR, I. N.; RITACCO, V. An update on bovine tuberculosis programmes in Latin American and Caribbean countries. Veterinary Microbiology, v. 112, n. 2-4, p. 111-118, 2006. doi: 10.1016/j.vetmic.2005.11.033.

KLEIN-GUNNEWIEK, M. F. C.; AMAKU, M.; DIAS, R. A.; FERREIRA, F.; GITTI, C. B.; PEREIRA, L. A.; FIGUEIREDO, V. C. F.; LOBO, J. R.; GONÇALVES, V. S. P.; FERREIRA NETO J. S. Epidemiological situation of bovine brucellosis in the State of Rio de Janeiro, Brazil. Arquivo Brasileiro de Medicina Veterinária e Zootecnia, v. 61, p. 77-84, 2009. Supplement 1.

KURODA, R. B. S.; NEGREIROS, R. L.; OSSADA, R.; FERREIRA NETO, J. S.; AMAKU, M.; DIAS, R. A.;
TELLES, E. O.; GRISI-FILHO, J. H. H.; HEINEMANN, M. B.; FERREIRA, F. Method for determining bovine brucellosis vaccination coverage. Semina: Ciências Agrárias, v. 37, n. 5, p. 3759-3766, 2016. Supplement 2. doi: 10.5433/1679-0359.2016v37n5Supl2p3759.

LAGE, A. P.; ROXO, E.; MÜLLER, E.; POESTER, F.; CAVALLÉRO, J. C. M.; FERREIRA NETO, J. S.; MOTA, P. M. P. C.; GONÇALVES, V. S. P. Programa nacional de controle e erradicação da brucelose e da tuberculose animal (PNCEBT). Brasília: Ministério da Agricultura, Pecuária e Abastecimento, 2006. 184 p. (Manual técnico).

LEAL FILHO, J. M.; BOTTENE, I. F. N.; MONTEIRO, L. A. R. C.; PELLEGRIN, A. O.; GONÇALVES, V. S. P.; FERREIRA, F.; DIAS, R. A.; AMAKU, M.; TELLES, E. O.; GRISI-FILHO, J. H. H.; HEINEMANN, M. B.; FERREIRA NETO, J. S. Control of bovine brucellosis from 1998 to 2009 in the state of Mato Grosso do Sul, Brazil. Semina: Ciências Agrárias, v. 37, n. 5, p. 3467-3478, 2016. Supplement 2. doi: 10.5433/1679-0359.2016v37n5Supl2p3467.

LIMA, P. B.; NASCIMENTO, D. L.; ALMEIDA, E. C.; PONTUAL,K.A.Q.;AMAKU,M.;DIAS, R.A.;FERREIRA, F.; GONÇALVES, V. S. P.; TELLES, E. O.; GRISI-FILHO, J. H. H.; HEINEMANN, M. B.; SILVA, J. C. R.; FERREIRA NETO, J. S. Epidemiological situation of bovine tuberculosis in the state of Pernambuco, Brazil. Semina: Ciências Agrárias, v. 37, n. 5, p. 3601-3610, 2016. Supplement 2. doi: 10.5433/1679-0359.2016v37n5Supl2p3601.

MALDONADO, J.; KOWALSKI, A.; MILLA, M.; RODRÍGUEZ, M.; VILLASMIL, C. Implementación de la prueba del anillo en leche y elisa indirecto para el diagnóstico de brucelosis en rebaños doble propósito del estado Lara, Venezuela. Revista Científica, v. 20, n. 3, p. 240-244, 2010.

MANRRIQUE, S. J. J. Estudio epizootiológico de brucelosis bovina en el departamento de Santa Cruz. 2005. Tese (Graduação) - Facultad de Medicina Veterinaria y Zootecnia, Universidad Autonoma Gabriel Rene Moreno, Bolivia. Available from: <https://goo.gl/1tFqy3>. Viewed: 10 Aug. 2017.

MARÍN, G. P. G. Determinacion de la tuberculosis bovina en hatos lecheros, Cantón Los Chacos. 2005. 
Tese (Graduação) - Facultad de Medicina Veterinaria y Zootecnia, Universidad Autonoma Gabriel Rene Moreno, Bolivia. Available from: <https://goo.gl/oRuAb8>. Viewed: 10 Aug. 2017.

MARVULO, M. F. V.; FERREIRA, F.; DIAS, R. A.; AMAKU, M.; GROFF, A. C. M.; GONÇALVES, V. S. P.; FIGUEIREDO, V. C. F.; LOBO, J. R.; FERREIRA, NETO J. S. Epidemiological situation of bovine brucellosis in the State of Rio Grande do Sul, Brazil. Arquivo Brasileiro de Medicina Veterinária e Zootecnia, v. 61, p. 93-102, 2009. Supplement 1. doi: 10.1590/S0102-09352009000700012.

MELEAN, A. R. Situación de la brucelosis bovina en las provincias Andrés Ibáñez, Warnes, Obispo Santiestevan y el municipio de Portachuelo de la provincia Sara del departamento de Santa Cruz. 2005. Tese (Graduação) Facultad de Medicina Veterinaria y Zootecnia, Universidad Autonoma Gabriel Rene Moreno, Bolivia. Available from: <https://goo.gl/pj9qQH>. Viewed: 10 Aug. 2017.

MEZA, C.A.;MORALES, C. S.;ARA, G. M.; MANCHEGO. S. A.; CALLE, E. S.; ANGULO, J. C. Seroprevalencia de brucelosis bovina en el distrito de Puerto Inca, Huánuco. Revista de Investigaciones Veterinarias del Perú, v. 21, n. 2, p. 223-226, 2010. doi: 10.15381/rivep.v21i2.141.

MOSQUERA, O.; FREITEZ, R.; RUMBOS, A. T. Vigilancia epidemiológica de la brucelosis bovina en la Parroquia Buria, Municipio Simón Planas, estado Lara. Periodo 2006-2007. Zootecnia Tropical, v. 27, n. 3, p. 263-270, 2009.

NEGREIROS, R. L.; DIAS, R. A.; FERREIRA, F.; FERREIRA NETO, J. S.; GONÇALVES, V. S. P.; SILVA, M. C. P.; FIGUEIREDO, V. C. F.; LOBO, J. R.; FREITAS, J.; AMAKU, M. Epidemiologic situation of bovine brucellosis in the State of Mato Grosso, Brazil. Arquivo Brasileiro de Medicina Veterinária e Zootecnia, v. 61, p. 56-65, 2009. Supplement 1. doi: 10.1590/S010209352009000700008.

NÉSPOLI, J.M. B.; NEGREIROS, R. L.; AMAKU, M.; DIAS, R. A.; FERREIRA, F.; TELLES, E. O.; HEINEMANN, M. B.; GRISI-FILHO, J. H. H.; GONÇALVES, V. S. P.; FERREIRA NETO, J.S. Epidemiological situation of bovinetuberculosis in the state of Mato Grosso, Brazil. Semina: Ciências
Agrárias, v. 37, n. 5, p. 3589-3600, 2016. Supplement 2. doi: 10.5433/1679-0359.2016v37n5Supl2p3589.

OGATA, R. A.; GONÇALVES, V. S. P.; FIGUEIREDO, V. C. F.; LOBO, J. R.; RODRIGUES, A. L.; AMAKU, M.; FERREIRA, F.; FERREIRA NETO, J. S.; DIAS, R. A. Epidemiological situation of bovine brucellosis in the State of Tocantins, Brazil. Arquivo Brasileiro de Medicina Veterinária e Zootecnia, v. 61, p. 126-134, 2009. Supplement 1. doi: 10.1590/S0102-093520090007 00016.

OLIVEIRA, L. F.; DORNELES, E. M. S.; MOTA, A. L. A. A.; GONÇALVES, V. S. P.; FERREIRA NETO, J. S.; FERREIRA, F.; DIAS, R. A.; TELLES, E. O.; GRISIFILHO, J. H. H.; HEINEMANN, M. B.; AMAKU, M.; LAGE, A. P. Seroprevalence and risk factors for bovine brucellosis in Minas Gerais State, Brazil. Semina: Ciências Agrárias, v. 37, n. 5, p. 3449-3446, 2016. Supplement 2. doi: 10.5433/1679-0359.2016v37n5Supl2p3449.

ORTIZ, P. M. W. Diagnostico de la tuberculosis bovina en cabañas nelore mediante el metodo ELISA (juego de prueba para el gamma - interferon en respuesta al Mycobacterium bovis). 2001. Tese (Graduação) - Facultad de Medicina Veterinaria y Zootecnia, Universidad Autonoma Gabriel Rene Moreno, Bolivia. Available from: $<$ https://goo.gl/S4wv2p>. Viewed: 10 Aug. 2017.

PÉREZ, F. P.; ORTIZ, W. B.; PORTAELS, F.; RIGOUTS, L.; LINDEN, A. Situation of bovine tuberculosis in Ecuador. Revista Panamericana de Salud Publica, v. 30, n. 3, p. 279-286, 2011.

POULSEN, K. P.; HUTCHINS, F. T.; MCNULTY, C. M.; TREMBLAY, M.; ZABALA, C.; BARRAGAN, V.; LOPEZ, L.; TRUEBA, G.; BETHEL, J. W. Brucellosis in dairy cattle and goats in northern Ecuador. American Journal of Tropical Medicine and Hygiene, v. 90, n. 4, p. 712-715, 2014. doi: 10.4269/ajtmh.13-0362.

QUEIROZ, M. R.; GROFF, A. C. M.; SILVA, N. S.; GRISI-FILHO, J. H. H.; AMAKU, M.; DIAS, R. A.; TELLES, E. O.; HEINEMANN, M. B.; FERREIRA NETO, J. S.; GONÇALVES, V. S. P.; FERREIRA, F. Epidemiological status of bovine tuberculosis in the state of Rio Grande do Sul, Brazil. Semina: Ciências 
Agrárias, v. 37, n. 5, p. 3647-3658, 2016. Supplement 2. doi: 10.5433/1679-0359.2016v37n5Supl2p3647.

RIBEIRO, L. A.; GONÇALVES, V. S. P.; FRANCISCO, P. F. C.; MOTA, A. L. A. A.; NASCIMENTO, G. T.; LICURGO, J. B.; FERREIRA, F.; GRISI-FILHO, J. H. H.; FERREIRA NETO, J. S.; AMAKU, M.; DIAS, R. A.; TELLES, E. O.; HEINEMANN, M. B.; BORGES, J. R. J. Epidemiological status of bovine tuberculosis in the Federal District of Brazil. Semina: Ciências Agrárias, v. 37, n. 5, p. 3561-3566, 2016. Supplement 2. doi: 10.5433/1679-0359.2016v37n5Supl2p3561.

RIVERA, S.; GIMÉNEZ, J. F. La tuberculosis bovina en Venezuela: patogénesis, epidemiología, respuesta inmunitaria y nuevas alternativas para el diagnóstico. REDVET. Revista electrónica de Veterinaria, v. 11, n. 9, p.1-27, 2010.

ROBINSON, T. P.; WINT, G. R. W.; CONCHEDDA, G.; VAN BOECKEL, T. P.; ERCOLI, V.; PALAMARA, E.; CINARDI, G.; D'AIETTI, L.; HAY, S. I.; GILBERT, M. Mapping the global distribution of livestock. PloS One, v. 9, n. 5, p. e96084, 2014. doi: 10.1371/journal.pone.0096084.

ROCHA, W. V.; GONÇALVES, V. S. P.; COELHO, C. G. N. F. L.; BRITO, W. M. E. D.; DIAS, R. A.; DELPHINO, M. K. V. C.; FERREIRA, F.; AMAKU, M.; FERREIRA NETO, J. S.; FIGUEIREDO, V. C. F.; LOBO, J. R.; BRITO, L. A. B. Epidemiological status of bovine brucellosis in the State of Goiás, Brazil. Arquivo Brasileiro de Medicina Veterinária e Zootecnia, v. 61, p. 27-34, 2009. Supplement 1. doi: 10.1590/S0102-09352009000700006.

ROCHA, W. V.; JAYME, V. S.; MOTA, A. L. A. A.; BRITO, W. M. E. D; PIRES, G. R. C; GRISI-FILHO, J. H. H; DIAS, R. A.; AMAKU, M.; TELLES, E. O.; HEINEMANN, M. B.; FERREIRA, F.; FERREIRA NETO, J. S.; GONÇALVES, V. S. P. Prevalence and herd-level risk factors of bovine tuberculosis in the State of Goiás, Brazil. Semina: Ciências Agrárias, v. 37, n. 5, p. 3625-3628, 2016. Supplement 2. doi: 10.5433/1679-0359.2016v37n5Supl2p3625.

SÁNCHEZ, R. D.; ROSADIO, A. R. Prevalencia de la tuberculosis bovina en la provincia de Parinacochas, Ayacucho. Revista de Investigaciones Veterinarias del Perú, v. 13, n. 2, p. 100-102, 2002. doi: 10.15381/rivep.v13i2.7341.
SIKUSAWA, S.; AMAKU, M.; DIAS, R. A.; FERREIRA NETO, J. S.; MARTINS, C.; GONÇALVES, V. S. P.; FIGUEIREDO, V. C. F. Epidemiological situation of bovine brucellosis in the State of Santa Catarina, Brazil. Arquivo Brasileiro de Medicina Veterinária e Zootecnia, v. 61, p. 103-108, 2009. Supplement 1. doi: 10.1590/S010209352009000700013.

SILVA, M. C. P.; GONÇALVES, V. S. P.; MOTA, A. L. A. A.; KOLODA, M.; FERREIRA NETO, J. S.; GRISIFILHO, J. H. H; DIAS, R. A.; AMAKU, M.; TELLES, E. O.; FERREIRA, F.; HEINEMANN, M. B.; ALFIERI, A. A.; MULLER, E. E. Prevalence and herd-level risk factors for bovine tuberculosis in the state of Paraná, Brazil. Semina: Ciências Agrárias, v. 37, n. 5, p. 3611-3624, 2016a. Supplement 2. doi: 10.5433/1679-0359.2016v37n5Supl2p3611.

SILVA, N. S.; GROFF, A. C. M.; VIDOR, A. C. M.; GRISIFILHO, J.H.H.; HEINEMANN, M.B.; DIAS, R. A.; TELLES, E. O.; GONÇALVES, V. S. P.; AMAKU, M.; FERREIRA, F.; FERREIRA NETO, J. S. Epidemiological situation of bovine brucellosis after implementation of a vaccination program in Rio Grande do Sul state, Brazil. Semina: Ciências Agrárias, v. 37, n. 5, p. 3519-3520, 2016b. Supplement 2. doi: 10.5433/1679-0359.2016v37n5Supl2p3519.

SILVA, V. G. S. O.; DIAS, R. A.; FERREIRA, F.; AMAKU, M.; COSTA, E. L. S.; LOBO, J. R.; FIGUEIREDO, V. C. F.; GONÇALVES, V. S. P.; FERREIRA NETO, J. S. Situação epidemiológica da brucelose bovina no Estado de Sergipe. Arquivo Brasileiro de Medicina Veterinária e Zootecnia, v. 61, p. 109-117, 2009. Supplement 1. doi: 10.1590/S010209352009000700014.

SOTA, M. D.; BAGNAT, E.; CONSENTINO, B.; NICOLA, A. Aproximación a la determinación de la prevalencia nacional de la brucelosis bovina. Revista del Colegio de Veterinarios de la Provincia de Buenos Aires, v. 11, n. 35, p. 31-35, 2006.

TIQUE, V.; GONZÁLEZ, M.; MATTAR, S. Seroprevalencia de Brucella abortus en bovinos del departamento de Córdoba. Revista U.D.C.A Actualidad \& Divulgación Científica, v. 12, n. 2, p. 51-59, 2009.

TORRES, P. M. Situación de la tuberculosis bovina en la República Argentina. Servicio Nacional de Sanidad y 
Calidad Agroalimentaria (Senasa), Buenos Aires, 2015. Available from: <https://goo.gl/pmGhKP>. Viewed: 6 June 2018.

URUGUAY. Ministerio de Ganadería, Agricultura y Pesca. Dirección General de Servicios Ganaderos. Boletín de comunicaciones. Montevideo: Digesega, 2015.25 p. Available from: <https://goo.gl/ZYrKir>. Viewed: 14 Aug. 2017.

VARGAS, F. J. Brucellosis in Venezuela. Veterinary Microbiology, v. 90, n. 1-4, p. 39-44, 2002. doi: 10.1016/ S0378-1135(02)00243-2.

VELOSO, F. P.; BAUMGARTEN, K. D.; MOTA, A. L. A. A.; FERREIRA, F.; FERREIRA NETO, J. S.; GRISIFILHO, J. H. H.; DIAS, R. A.; AMAKU, M.; TELLES, E. O.; HEINEMANN, M. B.; GONÇALVES, V. S. P. Prevalence and herd-level risk factors of bovine tuberculosis in the State of Santa Catarina, Brazil. Semina: Ciências Agrárias, v. 37, n. 5, p. 3659-3672, 2016. Supplement 2. doi: 10.5433/1679-0359.2016v37n5Supl2p3659.

VENDRAME, F. B.; AMAKU, M.; FERREIRA, F.; TELLES, E. O.; GRISI-FILHO, J. H. H.; GONÇALVES, V. S. P.; HEINEMANN, M. B.; FERREIRA NETO, J. S.; DIAS, R. A. Epidemiologic characterization of bovine tuberculosis in the State of Rondônia, Brazil. Semina: Ciências Agrárias, v. 37, n. 5, p. 3639-3646, 2016. Supplement 2. doi: 10.5433/1679-0359.2016v37n5Supl2p3639.

VENTOCILlA, G. S.; DELGADO, C. A.; RIVERA, G. H.; EVARISTO, R. R. Seroprevalencia de Brucella sp. en bovinos del distrito de Tarma, Junín. Revista de Investigaciones Veterinarias del Perú, v. 20, n. 2, p. 345-349, 2011. doi: 10.15381/rivep.v20i2.639.

VILLAR, K. S.; AMAKU, M.; DIAS, R. A.; FERREIRA NETO, J. S.; BENITEZ, F.; GONÇALVES, V. S. P.; FIGUEIREDO, V. C. F.; LOBO, J. R.; FERREIRA, F. Situação epidemiológica da brucelose bovina no Estado de Rondônia. Arquivo Brasileiro de Medicina Veterinária e Zootecnia, v. 61, p. 85-92, 2009. Supplement 1. doi: 10.1590/S0102-09352009000700011.

WAARD, J. H. Ordeñando micobacterias del ganado? Impacto económico y en salud de Tuberculosis bovina y Paratuberculosis en Colombia. Revista MVZ Córdoba, v. 15, n. 2, p. 2037-2040, 2010.

WIKIPEDIA CONTRIBUTORS. South America. Wikipedia: The Free Encyclopedia, [S.1.], 2018. Available from: <https://goo.gl/4oHrM8>. Viewed: 11 Dec. 2017.

WORLD ORGANISATION FOR ANIMAL HEALTH. Foot and Mouth Disease (FMD). Paris: OIE, 2017. Available from: <https://goo.gl/WYt7ap>. Viewed: 6 June 2018.

WORLD ORGANISATION FOR ANIMAL HEALTH. Handistatus II. Paris: OIE, 2014. Available from: < https:// goo.gl/S9qnLw>. Viewed: 6 June 2018.

ZAVALA, D. I.; MORALES, C. S.; HUAMÁN, U. H.; ANGULO, J. C. Presencia de brucelosis bovina en el distrito de Codo del Pozuzo, Huánuco. Revista de Investigaciones Veterinarias del Perú, v. 22, n. 1, p. 72-75, 2011. doi: 10.15381/rivep.v22i1.125. 